\title{
Assessing the impact of climate change on brown trout (Salmo trutta fario) recruitment
}

\author{
Julian Junker • Florian U. M. Heimann • Christoph Hauer • Jens M. Turowski • \\ Dieter Rickenmann $\cdot$ Massimiliano Zappa $\cdot$ Armin Peter
}

Received: 10 December 2013/Revised: 26 September 2014/Accepted: 29 September 2014/Published online: 4 November 2014 (C) Springer International Publishing Switzerland 2015

\begin{abstract}
Climate change influences air temperature and precipitation, and as a direct consequence, the annual discharge pattern in rivers will change as climate warming continues. This has an impact on bedload transport and consequently on aquatic life, because coarse sediments in streams provide important habitat for many species. Salmonids, for example, spawn in gravel, and during their early life stages live in or on top of the substrate. We used a multiple model approach to assess how predicted discharge changes affect bedload transport and the vulnerable early life stages of brown trout (Salmo trutta fario) in a prealpine catchment in Switzerland. In the study area, future discharge scenarios predict an increased frequency of flood occurrence in
\end{abstract}

Handling editor: Nicholas R. Bond

Electronic supplementary material The online version of this article (doi:10.1007/s10750 0142073 4) contains supple mentary material, which is available to authorized users.

J. Junker · A. Peter $(\square)$

Department of Fish Ecology and Evolution, Center of Ecology, Evolution and Biochemistry,

EAWAG Swiss Federal Institute of Aquatic Science and Technology, Seestrasse 79, 6047 Kastanienbaum, Switzerland

e mail: armin.peter@eawag.ch

F. U. M. Heimann - J. M. Turowski - D. Rickenmann · M. Zappa

WSL Swiss Federal Institute for Forest,

Snow and Landscape Research, 8903 Birmensdorf,

Switzerland winter and long-lasting low-flow periods in summer. As a result, bed erosion will become more frequent during winter, leading to less stable spawning grounds and deeper scouring, but during summer, an improvement in habitat diversity can be expected, which is advantageous for young-of-the-year fish. To face the future challenges of climate change, we recommend widening of riverbeds and improvements in longitudinal connectivity.

Keywords sedFlow - Salmo trutta fario . Bedload transport $\cdot$ Scouring $\cdot$ Mesohabitat $\cdot$ Spawning

\section{Introduction}

It is now generally accepted that the atmosphere is warming, to a large part due to anthropogenic influences. The changing climate is altering precipitation patterns. The last two centuries have seen an

\footnotetext{
C. Hauer

Christian Doppler Laboratory for Advanced Methods in River Monitoring, Modelling and Engineering, Department for Water Atmosphere Environment, IWHW Institute for Water Management, Hydrology and Hydraulic Engineering, BOKU University of Natural Resources and Life Sciences, Muthgasse 107, 1190 Vienna, Austria

J. M. Turowski

Helmholtz Centre Potsdam, GFZ German Research

Centre for Geosciences, Telegrafenberg, 14473 Potsdam, Germany
} 
increase in precipitation during winter and spring months in the northern regions of the alps (Brunetti et al., 2006), a trend that is likely to continue in future. In addition, a larger fraction of winter precipitation will fall in the form of rain rather than snow, snowmelt will have an earlier onset and the snow line will shift upwards to higher altitudes (Birsan et al., 2005; Parry et al., 2007; Scheurer et al., 2009). In high mountain regions, glaciers are receding, and the amount of water stored as ice is declining. As a result, the seasonal discharge regime in rivers will continue to change (Parry et al., 2007). Especially for the European Alps, a substantial temporal shift in runoff is expected (Horton et al., 2006). For streams at altitudes between 500 and 1,500 m.a.s.1., several studies predict increased winter runoff, 0.52 month earlier but reduced snowmelt-induced peak flows and reduced summer runoff (Jasper et al., 2004; Zierl \& Bugmann, 2005; Horton et al., 2006; BAFU, 2012). It thus seems likely that climate change will affect flooding and therefore bedload transport in Swiss mountain catchments over the coming 40100 years (OcCC \& ProClim, 2007).

For many aquatic species, coarse sediment in streams provides an important habitat, particularly for reproduction and for early life stages. For salmonid populations, the area and distribution of suitable spawning gravel in rivers determine breeding success (Kondolf \& Wolman, 1993). Hence, large flood events transporting sediment can severely affect a population. Already Jager et al. (1999) stated that anticipated hydrological changes for mountain streams due to climate change have clear consequences for salmonid survival. We selected brown trout (Salmo trutta fario) as the target species. The early life cycle of brown trout is strongly associated with the river sediment and slow-flowing habitats. It initiates in autumn with the spawning time, followed by a phase called incubation. During the incubation, brown trout remain, first as eggs and afterwards as alevins, in the gravel bed. A study on seven alpine and prealpine rivers in Switzerland (Riedl \& Peter, 2013) found that spawning lasted from the end of October until the beginning of January. The spawning season was closely connected to water temperature and altitude. Riedl \& Peter (2013) also measured redd features like hydraulic parameters and channel bed properties. The observations were comparable to current literature results (e.g. Grost et al., 1990; Zimmer \& Power, 2006; Pulg et al.,
2013). However, a discrepancy was found for egg burial depth, which was measured in two different ways. Taken from the level of the accumulated overlaying gravel, burial depth ranged from 1 to $16 \mathrm{~cm}$ (mean 5.8, $\mathrm{SD}= \pm 2.6 \mathrm{~cm}$ ). Measured from the original bed level, the depth is between -9 and $13 \mathrm{~cm}(3.8 \mathrm{~cm}, \mathrm{SD} \pm 3.2)$. These values, recorded by Riedl and Peter (2013), are lower than most mean literature values, which are between 4 and $20 \mathrm{~cm}$ (Elliott, 1984; Crisp, 1989; Grost et al., 1990). In spring, young brown trout, then called parr, emerge from the gravel into the water column (e.g. Elliott, 1994; Jonsson \& Jonsson, 2011).

The habitats of salmonid individuals are structured according to age and size, with juvenile fish using shallow, slow-flowing areas of the river, and moving into faster, deeper areas as they grow (Morantz et al., 1987; Keeley \& Grant, 1995). A way to describe this lateral and longitudinal mosaic of different river areas based on their physical condition, like water depth and flow velocity, is the use of hydro-morphological units (HMU), also called mesohabitats (Bisson et al., 1981; Frissell et al., 1986). However, so far there are only a limited number of studies investigating the effect of climate change on bedload transport in alpine catchments (e.g. Bathurst et al., 2004; Coulthard et al., 2012; Elliott et al., 2012; Layzell et al., 2012; Diodato et al., 2013) and an integration of interdisciplinary research linking climate change models to hydromorphology, and impacts on fish populations are lacking. We evaluate here the possible future impacts of climate change using brown trout as indicator species within this interdisciplinary framework. We assess in detail how predicted climatic changes affect discharge and bedload transport and thus the vulnerable early life stages of brown trout in a Swiss prealpine river (Kleine Emme), including time of spawning, incubation and the early phase as parr. To address these issues, we used a multi-scale modelling approach including the following elements:

(i) Simulation of future discharge conditions using input from general circulation models and regional climate models to a rainfall runoff model at the catchment scale.

(ii) Simulation of bed erosion and scour depths, during spawning and incubation time of brown trout, using a one-dimensional bedload transport model at the reach scale. 
(iii) Field investigations and hydrodynamic modelling of spawning ground stability and mesohabitats at the local scale.

These investigations are based on observed discharges for a control period (1980 2009) (hereafter abbreviated by CTRL) and on predicted discharges for the near (2021 2050) and far (2070 2099) future obtained from the rainfall runoff model.

\section{Materials and methods}

Study area

The river Kleine Emme is located in the prealpine area of central Switzerland (Fig. 1a). It rises from the Brienzer Rothorn Mountains $\left(46^{\circ} 48^{\prime} 5^{\prime \prime} \mathrm{N}, 8^{\circ} 4^{\prime} 0^{\prime \prime} \mathrm{E}\right.$, 1460 m.a.s.l.) and flows into the river Reuss $\left(47^{\circ} 4^{\prime} 2^{\prime \prime} \mathrm{N}, 8^{\circ} 17^{\prime} 16^{\prime \prime} \mathrm{O}, 434\right.$ m.a.s.l.), which belongs to the Rhine drainage. The river is $58-\mathrm{km}$ long, and its total catchment is $477 \mathrm{~km}^{2}$. The main geological units in the catchment are flysch, molasse conglomerate, and sandstone. The channel bed slope varies between 0.4 and $4 \%$. The Kleine Emme runoff regime is characterized by maximum yearly discharge in spring or early summer and the minimum discharge in the winter months. However, this pattern is more pronounced in the head reaches (Weingartner, 1992; BAFU, 2005). For the reach-scale analysis, a total length of $20 \mathrm{~km}$ of the Kleine Emme was simulated, starting downstream of Entlebuch and continuing until Littau, which is situated $5 \mathrm{~km}$ upstream of the confluence with the Reuss (Fig. 1b). For the local scale analysis, three reaches in the river were chosen, which are representative for the variability of the hydrogeological features of the Kleine Emme. Reach 1 has a total length of $205 \mathrm{~m}$ (upstream end at $\left.47^{\circ} 2^{\prime} 9.30^{\prime \prime} \mathrm{N}, 8^{\circ} 4^{\prime} 5.92^{\prime \prime} \mathrm{E}\right)$. It represents the degraded lower parts of the Kleine Emme. The channel is straightened, and the left bank is enforced by a concrete wall and three groynes. In addition, an artificial bed drop has been introduced to decrease channel bed slope. The substrate consists mainly of gravel, pebble, cobble, and boulders (Fig. 1c). The banks of Reach $2\left(47^{\circ} 1^{\prime} 38.14^{\prime \prime} \mathrm{N}, 8^{\circ} 3^{\prime} 59.89^{\prime \prime} \mathrm{E}\right.$, with a length of $170 \mathrm{~m}$ ) are natural. In this reach, the bed consists partly of exposed bedrock. The alluvial cover is thin and patchy, and consists of sand, gravel, pebble, cobble and boulders (Fig. 1d). The most diverse and near natural reach is Reach $3\left(47^{\circ} 0^{\prime} 0.03^{\prime \prime} \mathrm{N}\right.$, $8^{\circ} 3^{\prime} 39.49^{\prime \prime} \mathrm{E}, 210 \mathrm{~m}$ ). The substrate is dominated by cobbles, pebbles and boulders with a minor fraction of sand and gravel (Fig. 1e).

Catchment scale: impact of future climate change scenarios on discharge

The data for the hydrologic scenarios have been obtained from results of the CCHydro project (Bernhard \& Zappa, 2012; Kobierska et al., 2013), in which hydrologic simulations have been performed using the rainfall runoff model PREVAH (Viviroli et al., 2009). PREVAH is a well-established fully distributed rainfall runoff model specifically designed for alpine catchments. Hydrological computations for the near (2021 2050) and far future (2070 2099) used climate impact scenarios prepared by Bosshard et al. (2011), which have been obtained by the application of an advanced delta-change methodology (Gleick, 1986; Graham et al., 2007). A total of 10 scenarios for each future period could be considered here, stemming from the ENSEMBLES project (van der Linden \& Mitchell, 2009) and relating to the A1B emission scenario. The simulation within the CCHydro experiment has been validated at 70 gauging stations maintained by the Swiss Hydrological Service (Zappa et al., 2012). One of the verification points coincides with the main gauging station of the Kleine Emme (Table 1).

Hydrological models need careful calibration within a pre-defined control (CTRL) period. Following the procedure used by Kobierska et al. (2013), we modelled a 30-year period with PREVAH (1980 2009) as CTRL. The meteorological input forcing had a temporal resolution of one day and was obtained by interpolating data of the Swiss Federal Office for Meteorology and Climatology, MeteoSwiss (Begert et al., 2005). As presented by Schattan et al. (2013) and Kobierska et al. (2013), we adopted the fully distributed version of PREVAH for the hydrological impact study. This version allows for the assimilation of landuse change scenarios and for improved coupling with further impact models such as the bedload transport model presented below. We quantified model performance of the PREVAH simulations for the calibration and verification periods by computing the Nash criterion (NSE, Nash \& Sutcliffe, 1970) and by 

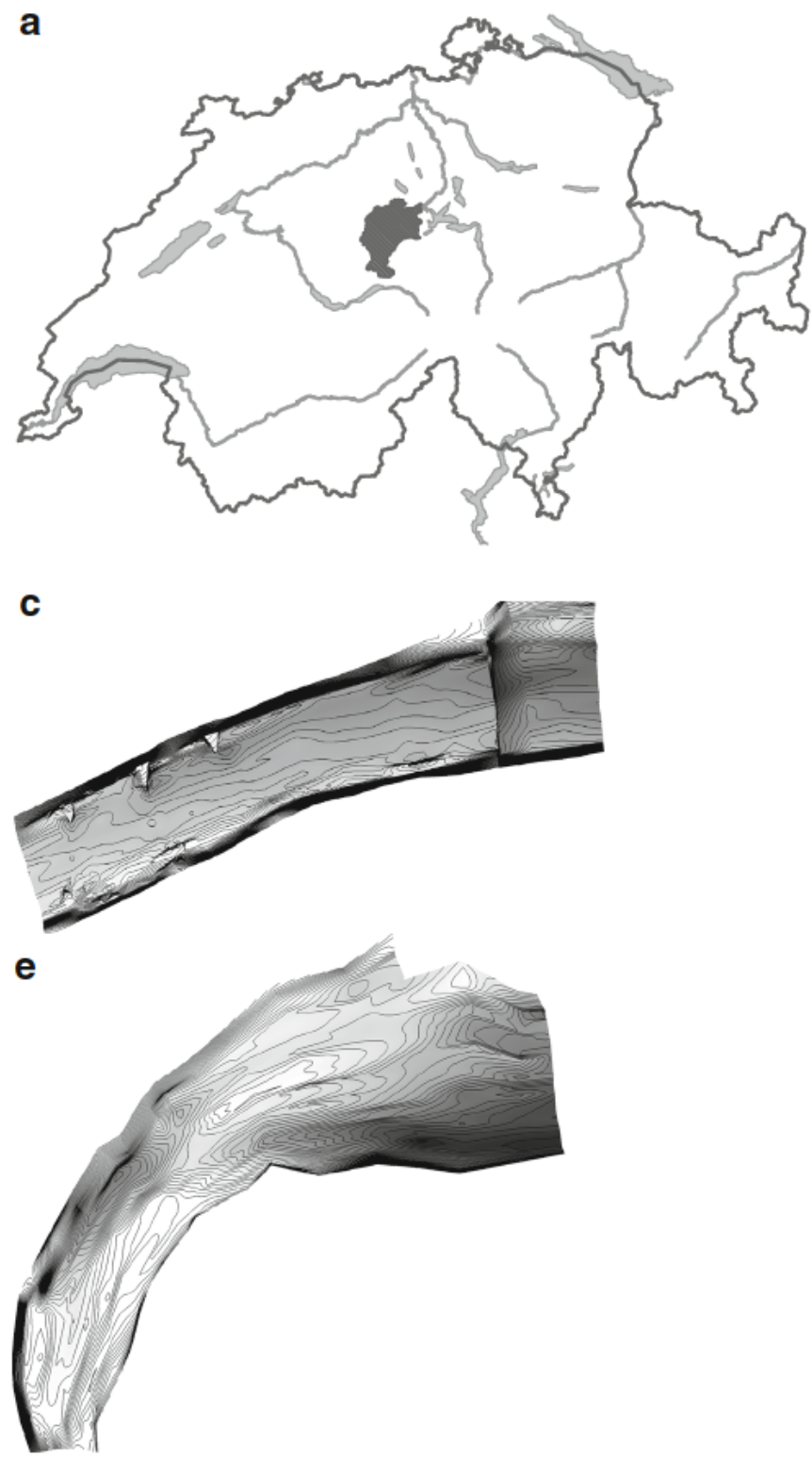

Fig. 1 a Map of Switzerland, showing the investigated catchment of the river Kleine Emme (shaded). b Kleine Emme and its main tributaries. The three test reaches are represented by square symbols. The two gauging stations are indicated by

assessing water volume error DV, which indicates the value in percent of the bias between simulated and observed discharge (Table 2). Further details on the setup used herein were presented by Schattan et al. (2013), Kobierska et al. (2013), and Köplin et al. (2010).
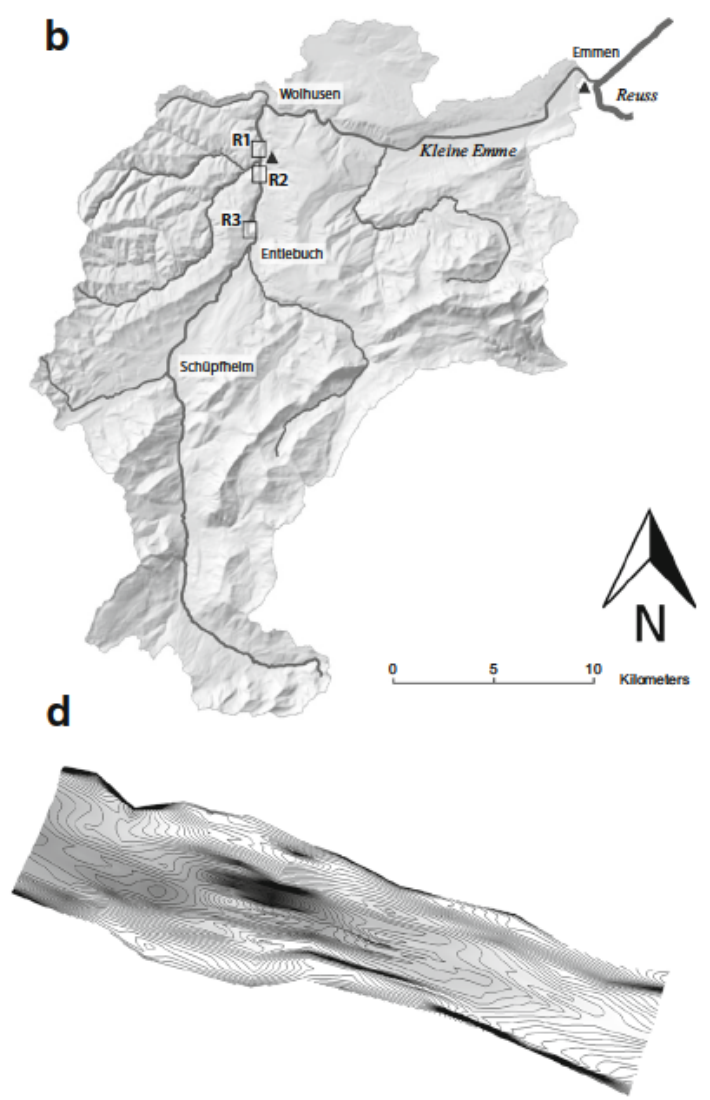

triangles. Digital terrain data used for mesohabitat modelling of possible future climate change impacts on brown trout reproduction and juvenile habitats: c Reach 1, d Reach 2, e Reach 3 (see "Parr phase" section)

Reach scale: climate change impacts on bedload transport and channel morphodynamics

For the bedload transport and channel morphodynamic simulations, we used the model sedFlow (Heimann et al., 2014a). This model performs a one-dimensional 
Table 1 Hydrological characteristics of the Kleine Emme River (BAFU, 2013)

\begin{tabular}{lll}
\hline Gaugingstation & Werthenstein & Littau \\
\hline NM30Q $\left(\mathrm{m}^{3} \mathrm{~s}^{-1}\right)$ & & 1.16 \\
MQ $\left(\mathrm{m}^{3} \mathrm{~s}^{-1}\right)$ & 11.0 & 15.6 \\
HQ2 $\left(\mathrm{m}^{3} \mathrm{~s}^{-1}\right)$ & 196 & 313 \\
HQ30 $\left(\mathrm{m}^{3} \mathrm{~s}^{-1}\right)$ & 417 & 595 \\
HQ100 $\left(\mathrm{m}^{3} \mathrm{~s}^{-1}\right)$ & 544 & 712 \\
\hline
\end{tabular}

$N M 30 Q$ minimal daily mean flow over 30 days, $M Q$ mean flow, $H Q_{x}$ high flow ( $x$ recurrence interval)

Table 2 Basic information on hydrological verification for the target area (gauging station Littau)

\begin{tabular}{lllll}
\hline $\begin{array}{l}\text { Catchment } \\
\left(\mathrm{km}^{2}\right)\end{array}$ & $\begin{array}{l}\text { Elevation } \\
\text { (m.a.s.1.) }\end{array}$ & \multicolumn{4}{l}{ Performance } \\
\cline { 3 - 5 } & & Period & NSE ( ) & DV (\%) \\
\hline 477 & Min: 431 & Cal & 0.823 & 1.9 \\
& Avg: 1,050 & VER & 0.831 & 5.8 \\
& Max: 2,300 & TOT & 0.828 & 4.0 \\
\hline
\end{tabular}

We indicate the performance (NSE and DV) of hydrological model PREVAH during calibration (CAL, 1984 1996), verification (VER, excl. 1984 1996) and for the whole control period (TOT, 1980 2009)

hydraulic routing of the runoff using a kinematic wave approach for a rectangular cross section. The boundaries of the simulated system have constant elevation and grain size distributions. Sediment input at the upstream boundaries is determined corresponding to the current discharge without limitations in sediment availability. The model has been developed for the simulation of bedload transport per grain size fraction in mountain streams. The modelling concept is similar to the one-dimensional bedload transport model for steep slopes presented by Chiari et al. (2010). To calculate bedload transport as a function of shear stress, an equation proposed by Rickenmann (2001) is used in combination with a reduced energy slope to account for macro-roughness effects (Rickenmann \& Recking, 2011). The use of a reduced energy slope significantly improves the prediction of bedload transport in steep mountain streams (Chiari et al., 2010; Nitsche et al., 2011; Rickenmann, 2012). The critical dimensionless shear stress for initiation of transport was determined using the empirical approach of Lamb et al. (2008). For slopes approaching zero, the equation of Lamb et al. (2008) predicts a

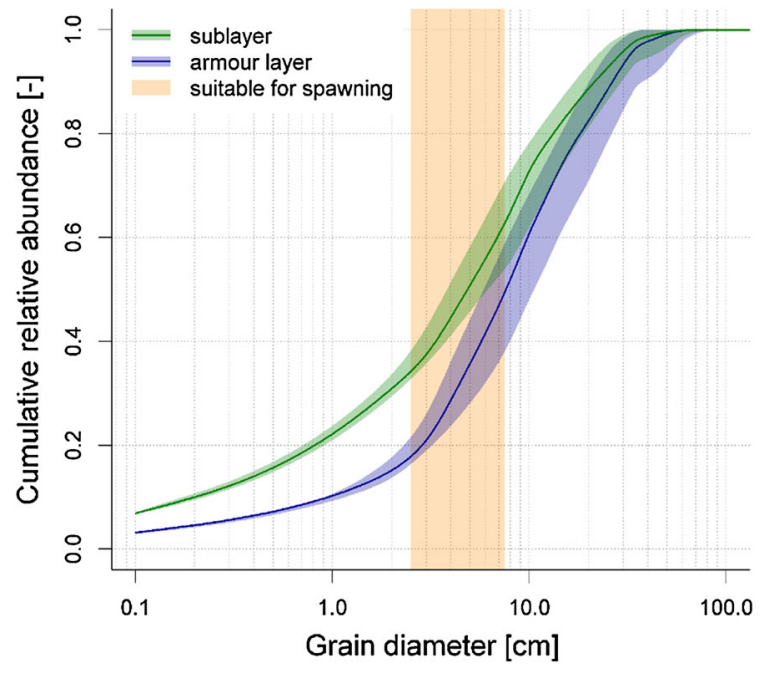

Fig. 2 Grain size distribution derived from 22 line by number samples recorded at the Kleine Emme. Solid lines represent the median. Shaded areas are confined by the quartiles

threshold value near zero, which is unrealistic. Therefore, a minimal critical dimensionless shear stress of 0.06 was used whenever the equation predicted lower values. This value of 0.06 performed best for the numeric reproduction of observed bed level changes and is close to 0.047 as proposed by Meyer-Peter \& Müller (1948). Grain size distributions were measured using the transect-by-number sampling method (Fehr, 1987) at 19 locations along the river profile. Following the Wentworth scale (Wentworth, 1922), gravel and cobble grain sizes are most dominant in the channel (Fig. 2).

The bedload transport model sedFlow was calibrated for the Kleine Emme for the period 20002005 for which independent measurements of sediment input and changes in bed elevation were available. For the simulation, the investigated $20 \mathrm{~km}$ river length of the Kleine Emme was subdivided into legs ranging in length from about $50200 \mathrm{~m}$. For each leg, two crosssectional profile measurements are available from September 2000 and November 2005, which served as a basis for the calibration of sedFlow. The agreement of modelled with observed cross-sectional changes was evaluated by comparing the simulated accumulated bedload transport with the one derived from observed bed level changes (Heimann et al., 2014b), resulting in a Nash Sutcliffe goodness-of-fit measure of 0.949 (Nash \& Sutcliffe, 1970). The parameter set 
from the model calibration runs was used for the simulations of both the CTRL and future periods (Badoux et al. 2014). The same initial conditions were used for all model runs, and only the hydrologic input was varied. Each run was started on April 16th and finished on April 15th of the following year. The summer months were used as priming for the spatial pattern of grain size distributions. Simulation state variables were recorded every three hours during low and intermediate flow and every $15 \mathrm{~min}$ when discharge exceeded its upper 90th percentile.

The analysis focused on the maximum erosion depth during incubation and the timing of lowest bed elevation during winter. These simulated variables are recorded for each leg along the river, during a single winter, for all different years within the study period (30 years in each of CTRL, near future, and far future), and for each available hydrologic/climatic scenario. To obtain the maximum erosion depth during incubation, the minimum bed elevation during the period from December 20th to April 15th was subtracted from the bed elevation on December 20th. The timing of the lowest bed elevation was assessed for the period between October 15th and April 15th of each simulated year. To characterize the effect of climate change on erosion depth and timing of the lowest bed level, spatial as well as temporal quantiles of the CTRL period were compared to the intervariability of the different hydrologic/climatic scenarios for both the near and far future.

To specify the spatial distribution of changes, we studied how simulated grain sizes and bed stability depend on the channel gradient. For this, we defined the bed to be stable when the maximum erosion depth did not exceed a threshold value of $5 \mathrm{~cm}$. This threshold is not only higher than the average egg burial depth of $3.8 \mathrm{~cm}$ as measured from the original bed level (Riedl \& Peter, 2013), but also slightly lower than the $5.2 \mathrm{~cm}$ as measured from the overlaying gravel at the redd.

Local scale: climate change impacts on habitat stability and distribution

\section{Terrestrial survey/DTM generation}

The bathymetric shape (main channel) of the three investigated sites at the local scale of the Kleine Emme has been measured by terrestrial survey
(17.7.2012 18.7.2012). A total station (Leica TC805) was used to survey all relevant morphological features for mesohabitat classification (e.g. gravel bars, Riffle-Pool features) based on cross-sectional measurements (Reach 1: 23 cross sections, Reach 2: 14 cross sections, Reach 3: 20 cross sections). Additional points were surveyed between those transects if important hydraulic (habitat) characteristics were observed (e.g. groynes and the related backwaters) to determine basics for high-quality Digital Terrain Models (DTMs). The terrestrial sampling points (Reach 1: 525 points, reach 2: 261 points, Reach 3: 453 points) were placed onto a regular grid in a second step before modelling. For the present study, the Surface Water Modelling System (SMS) was selected. SMS combines various algorithms for the generation of modelling meshes with boundaries of arbitrary shape and the interpolation of topographic data (French, 2003). Moreover, basic tools for presenting map, terrain and feature data are provided as a series of geographical information (using GIS polygons) (French, 2003). For DTM generation of the investigated sites at the Kleine Emme, a patch-based algorithm was used which automatically determines elongated quadrilaterals or triangular elements. In total, 11712 elements (Reach 1), 5902 elements (Reach 2), and 12838 (Reach 3) were used to provide bathymetric information for hydrodynamic numerical modelling (Fig. 1c e).

\section{Hydrodynamic numerical modelling}

For hydrodynamic numerical modelling, a twodimensional depth-averaged model was used to achieve the required abiotic resolution (e.g. flow velocity) for instream habitat studies on the meso- and microunit scale. The applied software Hydro as-2d (Nujic, 1999) calculates the hydraulic conditions (water depth, depth-averaged flow velocity, bottom shear stress) on a linear grid by a finite volume approach. Time was discretised using an explicit second-order Runge Kutta method, and the convective flow was calculated based on the Upwind scheme (Pironneau, 1989). The bed shear stress $\tau$, which was used as a parameter for determining spawning habitat stability during the period of reproduction (November January) or incubation (February April), was calculated for each node of the grid based on following formulas (Nujic, 2004): 
$\tau=\rho \cdot g \cdot h \cdot S_{\mathrm{f}}$,

$S_{\mathrm{f}}=\frac{v^{2}}{k_{\mathrm{str}}^{2} \cdot h^{\frac{4}{3}}}$,

where $\rho$ is the density of water $\left(1,000 \mathrm{kgm}^{-3}\right), g$ the acceleration due to gravity $\left(9.81 \mathrm{~ms}^{-2}\right), h$ the water depth at each node $(\mathrm{m}), S_{\mathrm{f}}$ the friction slope $(-), v$ the depth-averaged flow velocity at each node $\left(\mathrm{m} \mathrm{s}^{-1}\right)$ and $k_{\text {str }}$ is the roughness coefficient by Strickler (which is equal to the inverse of Mannings roughness coefficient).

To ensure steady state flow conditions (input discharge $=$ output discharge) for the investigated reaches, $30600 \mathrm{~s}(8.5 \mathrm{~h})$ were required as total modelling time for each of the 242 modelling runs (sum of all climate change scenarios and low-flow sensitivity testings). Moreover, discrete time steps of $900 \mathrm{~s}$ have been applied as computational and/or detailed output interval (e.g. flow velocity).

\section{Classification and stability testing of spawning ground and mesohabitats}

For the impact analysis of climate change on brown trout habitats at the Kleine Emme, the Mesohabitat Evaluation Model (MEM) was used (Hauer et al., 2009). The MEM model enables the determination and quantitative calculation of six significant different hydro-morphological units (mesohabitats). Based on depth-averaged flow velocity, water depth and bottom shear stress, the mesohabitats riffles and fast runs (as high energetic habitats), runs and pools (as moderate energetic habitats) shallow waters and backwaters (as low energetic habitats) can be numerically distinguished (Hauer et al., 2009). Furthermore, by knowing the hydrological characteristics (depth and flow velocity) of spawning grounds of a certain fish species, it is possible to identify suitable areas for reproduction within selected stretches. For engineering practice, the MEM-concept was implemented into a Java software application, which can be used for the post-processing of modelling results of three different two-dimensional (CCHE2D, River2D, Hydro as-2d) and two different three-dimensional models (RSIM-3D, SSIIM) (Tritthart et al., 2008). MEM-modelling results are presented in visual forms (plots) and/or quantified by area $\left(\mathrm{m}^{2}\right)$ and in relation to the total wetted area (\%).
The stability of the bed is assessed using a simple threshold criterion on the shear stress (Eq. 1). When the critical shear stress $\tau_{\mathrm{cr}}$ is exceeded locally for the discharge of interest, the bed is said to be unstable. Following the suggestion of Meyer-Peter \& Müller (1948), the value of $\tau_{\mathrm{cr}}$ is set to

$\tau_{\mathrm{cr}}=0.047 \cdot\left(\rho_{\mathrm{S}}-\rho\right) \cdot g \cdot d_{\mathrm{m}}$.

Here $\rho_{\mathrm{s}}$ is the density of the sediment $(=2,665$ $\mathrm{kgm}^{-3}$ ), and $d_{\mathrm{m}}$ is the characteristic grain size (m). Similar to mesohabitat evaluation, the bed stability for each of the hydro-morphological units is quantified by area $\left(\mathrm{m}^{2}\right)$ and in relation to the total planimetric extent (\%) of a specific habitat type (e.g. riffles). Note that the definition of bed stability in the MEM differs from the definition used in the reach-scale modelling approach (see "Bedload and morphodynamics" section).

We used the MEM to find suitable spawning grounds for reproduction in the three test reaches of the Kleine Emme. Our data for the suitable depth and flow velocity of spawning grounds are based on records during the years 2010 and 2011 by Riedl \& Peter (2013) in seven prealpine and alpine Swiss streams that are comparable to the Kleine Emme. These data were supplemented with additional spawning observations during this study in the Kleine Emme catchment in 2012, adding up to a total sample size of 124 redds for the present study. At three points on each redd (pit, middle and tail), depth, flow velocity at a depth of $60 \%$ of the water column and substrate were measured. By calculating the average of the three measured points, we produced the usability range of a maximal depth use which was between 0.15 and $0.2 \mathrm{~m}$, with a flow velocity of $0.45 \mathrm{~m} / \mathrm{s}$. Using the MEM, we searched, within the three river reaches, for all areas with the mentioned suitable abiotic characteristics under autumn lowflow conditions, and aligned them with our own observations in the test reaches of suitable spawning gravel (average size $3.1 \mathrm{~cm}$ ). If a patch showed the right depth, velocity, and substrate, we considered it as a designated spawning ground. These patches were tested for their stability under different discharges (4 $26 \mathrm{~m}^{3} \mathrm{~s}^{-1}$ ) using two representative grain diameters $\left(d_{\mathrm{m}}=20\right.$ and $\left.50 \mathrm{~mm}\right)$. Here we considered a patch as $100 \%$ stable if no movement of the bed surface was found. 
Sensitivity testing and distribution of mesohabitats under differing discharges

Mesohabitat distribution was modelled in the threetest reaches to investigate the sensitivity of available (suitable) habitat area for variable discharges of $412 \mathrm{~m}^{3} \mathrm{~s}^{-1}$. This range coincides with the lowest flow magnitude during the summer period (June, July, August) of each of the 10 climate scenarios. To determine and quantify the shifts in habitat availability during summer months (June, July, August) in the near and far future, the specific discharge of each of the 10 climate scenarios was modelled in a second analysis.

\section{Mesohabitat suitability for different brown trout age classes}

During October 2012, electrofishing surveys were conducted in the three-test reaches. Fishing was done within hydro-morphological units, according to the MEM and to pre-modelled mesohabitat distribution maps for the specific discharge during the fieldwork. Every mesohabitat type was sampled separately, and fish were kept in different tanks after. The fish were grouped into different age classes based on their lengths (according to our own observations, these are young of the year (YOY); $61130 \mathrm{~mm}$, subadult; $161210 \mathrm{~mm}$, and adult $>221 \mathrm{~mm}$ ). We calculated the relative frequency of fish density for each age class in a certain mesohabitat type, dividing number of fish caught by sampled mesohabitat area. By normalizing these values (the highest relative frequency of fish density of a mesohabitat type is given a value of one and the rest of the results are set in relation to it), we obtained an index of habitat suitability.

\section{Results}

Catchment scale

The yearly water balance of the catchment for the CTRL period 19802009 (Zappa et al., 2012) resulted in $1,505 \mathrm{~mm}$ precipitation, $980 \mathrm{~mm}$ discharge, $504 \mathrm{~mm}$ evapotranspiration and $20 \mathrm{~mm}$ storage change (Fig. 3). Storage change is due to different snow accumulation and groundwater storage between the beginning and the end of the simulation with PREVAH. The model predicts that under current conditions $11.5 \%$ of runoff is generated from snowmelt. The average discharge hydrograph of the CTRL period clearly indicates that the snowmelt governs the high-flow season between mid-March and mid-June (Fig. 3a).

The results obtained for the near future (Fig. 4a) already hint at a distinct increase of average discharge in the winter half-year. This is because of both the expected precipitation increase in winter (Bosshard et al., 2011), and the reduction of snow accumulation as a consequence of increased average temperature (i.e. a larger fraction of the winter precipitation falls as rain rather than as snow). The predicted average discharge in January to March is below the average value of present-day conditions in only one scenario. The average seasonal discharge maximum in spring is predicted to decrease in magnitude. In the near future, the discharge regime is predicted to be less seasonal. Most of the scenarios predict lower runoff in the summer season in comparison to the CTRL. Averaged over all ten realizations, the models predict no relevant change in the average annual water balance. Only the average contribution of snowmelt might be reduced from 11.5 to $8 \%$. Note that the individual scenarios result in predictions of runoff changes ranging between -8 and $+8 \%$ (Fig. 3a).

The further increase in temperature expected for the latter portion of the twenty first century (Bosshard et al., 2011) is cause of the further decrease in the predicted summer low-flow periods in the far future (Fig. 4b). The reduction of snow accumulation and strong increase in liquid precipitation in the winter will change the discharge regime in the Kleine Emme, resulting in a distinct runoff maximum in winter and long-lasting low-flow periods in the summertime. Again, the ten realizations show no clear change in the yearly water balance components, but the relative differences in the predictions for the ten scenarios increase. Specific scenarios result in predictions of runoff changes ranging between -14 and $+18 \%$.

\section{Reach scale}

\section{Bedload transport and morphodynamics}

Here, we use spatial and temporal percentiles to illustrate the model outputs. To obtain the spatial percentiles, the maximum erosion rate for each leg in the model was determined for a given simulated year. Out of these values, the desired spatial percentile was 


\section{a}

KIE - 2021 - Balance

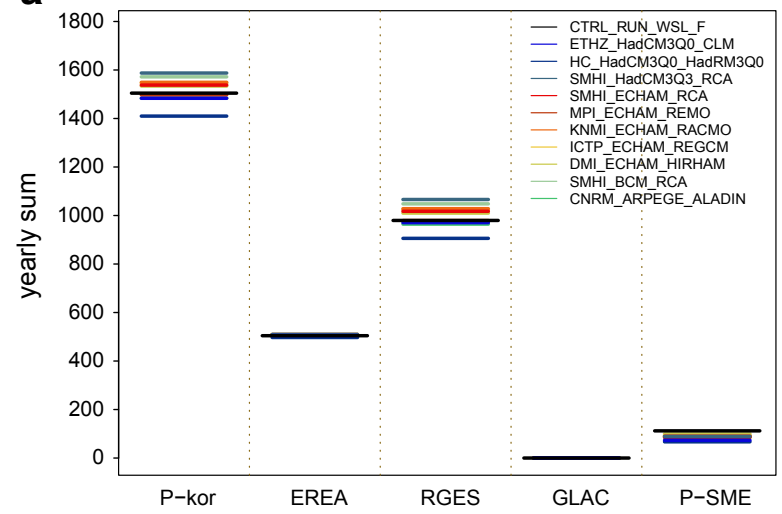

Fig. 3 Water balance scenarios for the "Kleine Emme" for the reference period (black line in both panels) and ten realizations for both future periods (coloured lines: left panel a 20212050 , right panel b 20702099 . The labels on the $x$ axis define the b

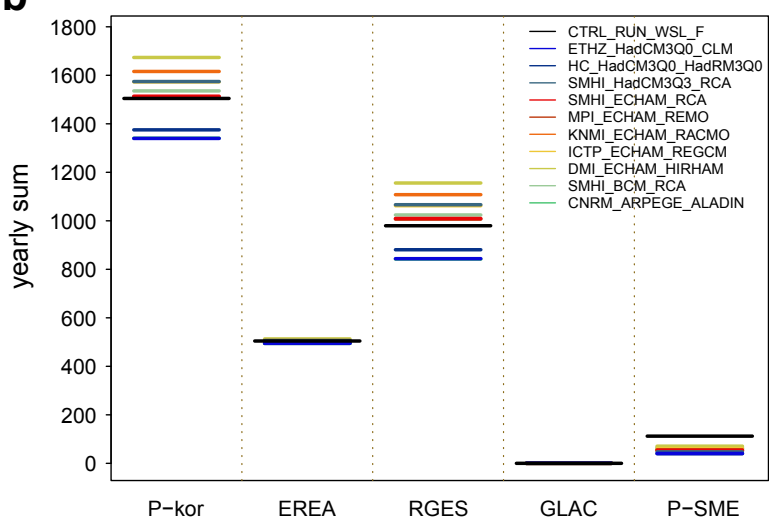

average water balance elements expressed in mm per year: precipitation (P kor), actual evapotranspiration (EREA), total discharge (RGES), glacier melt (GLAC) and snowmelt (P SME)

(a)

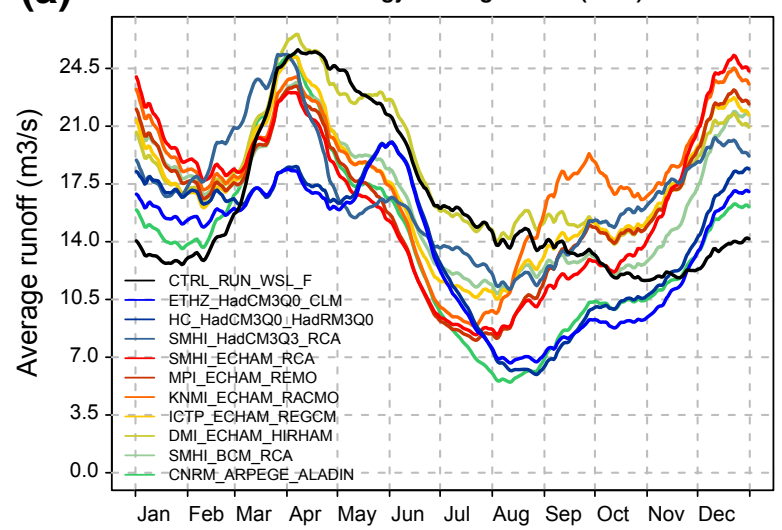

(b)

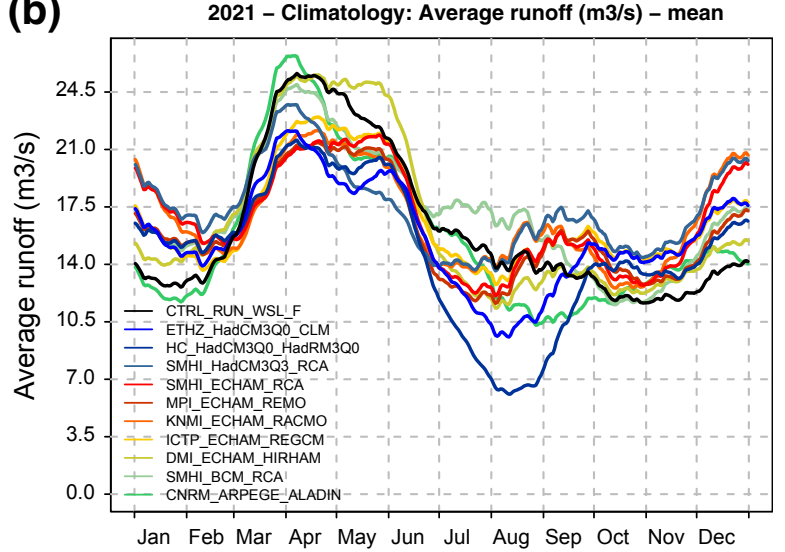

Fig. 4 Scenarios of mean discharge $\left(\mathrm{m}^{3} \mathrm{~s}^{-1}\right)$ for the "Kleine Emme" for the reference period (black line in both panels) and ten realizations for both future periods (colour lines: a 2021 2050, b 2070 2099). A centred 30 day averaging filter was applied

then calculated for each individual year (30 years for each of the near and far future). Temporal percentiles were calculated from the results for different years in the studied periods for a given spatial percentile. Only a slight increase of erosion depths is predicted for the near future, when the 75th spatial percentile is used (Fig. 5). The increase is more distinct for the far future, where it exceeds the range in predicted values obtained for the different hydrologic/climatic scenarios. Different temporal percentiles exhibit a qualitatively similar behaviour (Fig. 5). For other spatial percentiles, the picture is similar as well (see supplemental material). Thus, the increase of winter erosion depths appears to be consistent across all years and reaches.
During the sensitive phases of spawning and incubation of brown trout, the lowest bed elevation tends to occur at a later time than in the CTRL period (Fig. 6). In general, this means that the period in which erosion takes place continues for a longer time. The trend is clearer for the far future than for the near future.

The fraction of stable legs (i.e. the maximum erosion depth is less than $5 \mathrm{~cm}$ ) decreases in the future (Fig. 7). In general, legs with smaller slopes are more stable than legs with higher slopes. In addition, the number of unstable legs declines more steeply with increasing bed slope in the near future than in CTRL, and in the far future than in the near future. 


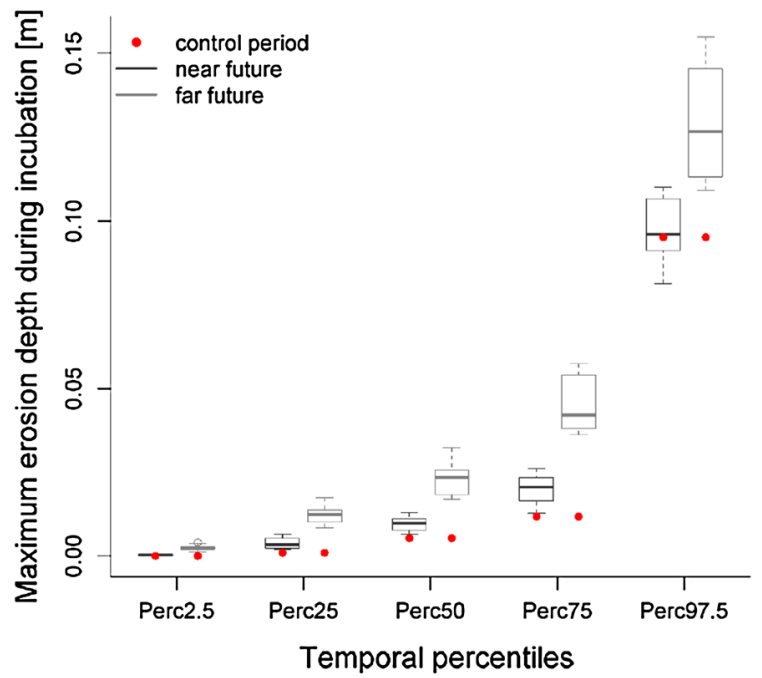

Fig. 5 Spatial 84th percentile of maximum scour depth during incubation. Temporal percentiles refer to years within the study period. The boxplots reflect the variability over the available hydrologic/climatic scenarios. The 84 th percentile value sepa rates those $16 \%$ reaches with larger erosion depths from those $84 \%$ reaches with smaller erosion depths. The abscissa represents the temporal percentiles of erosion depth. Years on the left part of the figure have little winter erosion, years on the right part have more intense winter erosion

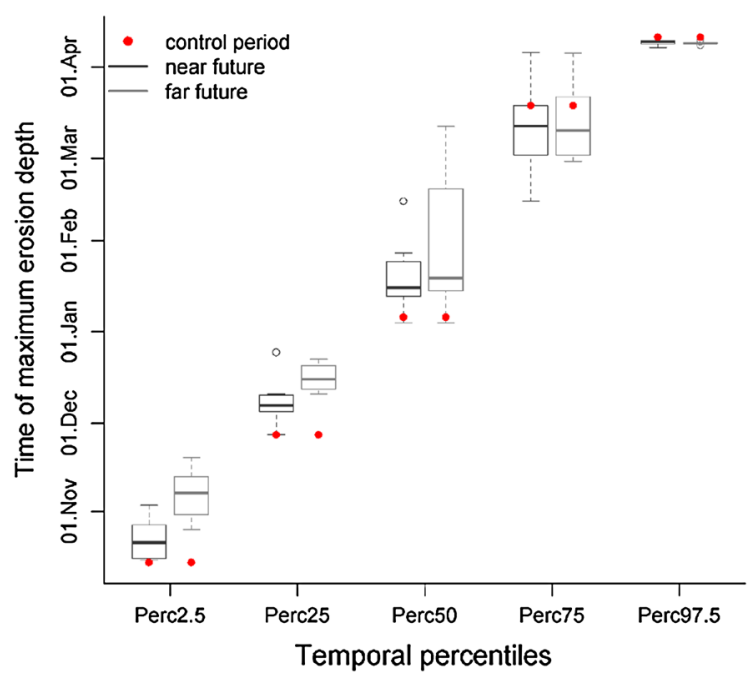

Fig. 6 Moment of minimum bed level occurrence. Temporal percentiles refer to years within the study period. The boxplots reflect the variability over the available hydrologic/climatic scenarios. Spatial and temporal percentiles are used as described for Fig. 5. Instead of the spatial 84 percentile the spatial median is used and the abscissa represents different years grouped according to early or late occurrence of maximum erosion

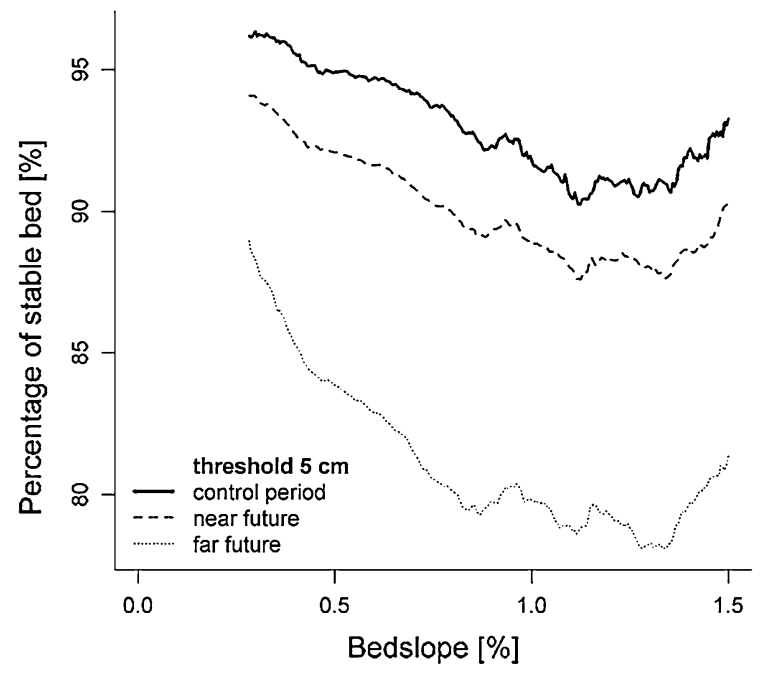

Fig. 7 Moving average of relative abundance of stable profiles compared to bedslope. The spatial distribution of erosion is shown as a function of channel slope $S$ with a moving window width of $\Delta S \quad 0.5 \%$. That means for a given slope $S$ all reaches with slopes in a range of $S \pm 0.25 \%$ are analysed. Among these reaches, the relative abundance of profiles is counted, for which the maximum erosion during incubation (Dec 20th to April 15th) does not exceed a threshold of $5 \mathrm{~cm}$. This relative abundance of stable profiles is given in the ordinate, while the abscissa shows the centre of the moving bed slope window

Generally, the median grain size of the surface layer $D_{50}$ at the beginning of incubation period (to be taken the 18th to 22nd December) increases with increasing channel bed slope $S$ (Fig. 8). Below a threshold bed slope of about $0.9 \%$, the vast majority of simulated $D_{50}$ 's are finer than $12 \mathrm{~cm}$. Above this threshold simulated $D_{50}$ 's range from about $10 \mathrm{~cm}$ to more than $40 \mathrm{~cm}$. The CTRL period as well as the near and the far future exhibit a similar behaviour.

\section{Local scale}

\section{Stability of spawning ground}

The selected spawning site in Reach 1 is stable for discharges between 4 and $5 \mathrm{~m}^{3} \mathrm{~s}^{-1}$ and the grain size $d_{\mathrm{m}}$ of 20 and $50 \mathrm{~mm}$ (Table 3). But the stability starts to decrease at discharges higher than $5 \mathrm{~m}^{3} \mathrm{~s}^{-1}$ and is totally unstable with a discharge of $11 \mathrm{~m}^{3} \mathrm{~s}^{-1}$ for the grain size of $20 \mathrm{~mm}$ diameter. Under this discharge, the same patch with a grain size $d_{\mathrm{m}}$ of $50 \mathrm{~mm}$ remains stable. The erosion starts at a discharge higher than 


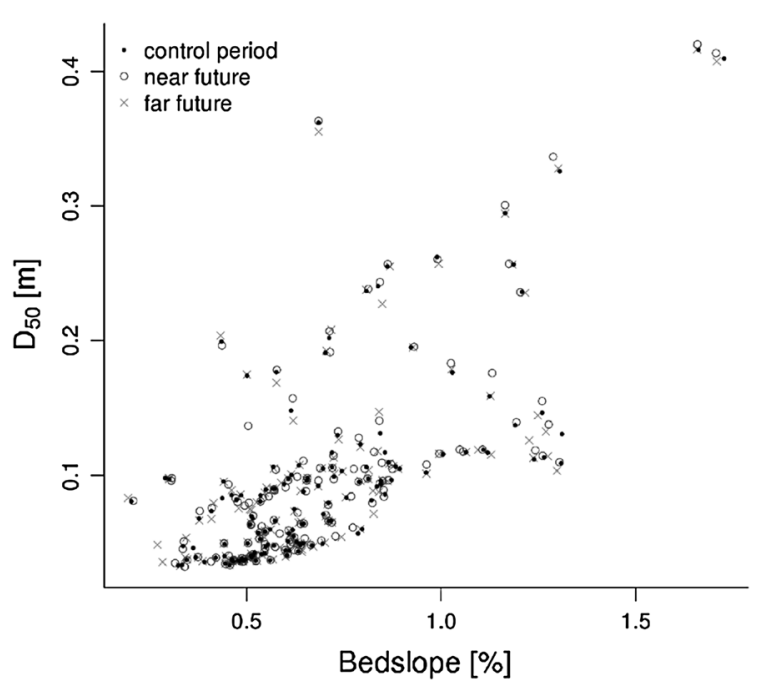

Fig. 8 Median grain diameter at individual simulation legs compared to bedslope. The values represent medians of the values calculated for 5 days at the beginning of the incubation period (18th to 22nd December) across all years and hydrologic/ climatic scenarios
$12 \mathrm{~m}^{3} \mathrm{~s}^{-1}$ and reaches $100 \%$ instability with more than $20 \mathrm{~m}^{3} \mathrm{~s}^{-1}$ water. The designated spawning site in Reach 2 is already partly unstable for the smaller grain size at a discharge of 4 , and $8 \mathrm{~m}^{3} \mathrm{~s}^{-1}$ is enough to reach $100 \%$ instability. The site is also unstable for the $d_{\mathrm{m}}=50 \mathrm{~mm}$ substrate with a discharge of $4 \mathrm{~m}^{3} \mathrm{~s}^{-1}$, but $100 \%$ instability requires discharges of more than $24 \mathrm{~m}^{3} \mathrm{~s}^{-1}$. The site in Reach 3 is the most unstable. At a discharge of $4 \mathrm{~m}^{3} \mathrm{~s}^{-1}$, just $2.65 \%$ of the bed area is stable with $d_{\mathrm{m}}=20 \mathrm{~mm}$, and $100 \%$ instability is reached at discharges smaller than $5 \mathrm{~m}^{3} \mathrm{~s}^{-1}$. Also with $d_{\mathrm{m}}=50 \mathrm{~mm}$, just $32.92 \%$ is stable with the smallest calculated discharge, and the $100 \%$ instability is reached for discharges under $11 \mathrm{~m}^{3} \mathrm{~s}^{-1}$ (Table 3).

\section{Sensitivity testing of flow variation}

In addition to the availability and the stability of spawning habitats, possible changes of the quantitative habitat distribution due to predicted climate change are of special interest, ostensibly for the early life stages of

Table 3 Stability analysis of possible suitable spawning areas of brown trout using variable grain sizes

\begin{tabular}{|c|c|c|c|c|c|c|c|c|c|c|c|c|}
\hline \multirow{3}{*}{$\begin{array}{l}\text { Discharge } \\
\left(\mathrm{m}^{3} \mathrm{~s}^{-1}\right)\end{array}$} & \multicolumn{4}{|c|}{ Reach 1} & \multicolumn{4}{|c|}{ Reach 2} & \multicolumn{4}{|c|}{ Reach 3} \\
\hline & \multicolumn{2}{|c|}{$d_{\mathrm{m}} 20 \mathrm{~mm}$} & \multicolumn{2}{|c|}{$d_{\mathrm{m}} 50 \mathrm{~mm}$} & \multicolumn{2}{|c|}{$d_{\mathrm{m}} 20 \mathrm{~mm}$} & \multicolumn{2}{|c|}{$d_{\mathrm{m}} 50 \mathrm{~mm}$} & \multicolumn{2}{|c|}{$d_{\mathrm{m}} 20 \mathrm{~mm}$} & \multicolumn{2}{|c|}{$d_{\mathrm{m}} 50 \mathrm{~mm}$} \\
\hline & $\begin{array}{l}\text { Stable } \\
\left(\mathrm{m}^{2}\right)\end{array}$ & $\begin{array}{l}\text { Stable } \\
(\%)\end{array}$ & $\begin{array}{l}\text { Stable } \\
\left(\mathrm{m}^{2}\right)\end{array}$ & $\begin{array}{l}\text { Stable } \\
(\%)\end{array}$ & $\begin{array}{l}\text { Stable } \\
\left(\mathrm{m}^{2}\right)\end{array}$ & $\begin{array}{l}\text { Stable } \\
(\%)\end{array}$ & $\begin{array}{l}\text { Stable } \\
\left(\mathrm{m}^{2}\right)\end{array}$ & $\begin{array}{l}\text { Stable } \\
(\%)\end{array}$ & $\begin{array}{l}\text { Stable } \\
\left(\mathrm{m}^{2}\right)\end{array}$ & $\begin{array}{l}\text { Stable } \\
(\%)\end{array}$ & $\begin{array}{l}\text { Stable } \\
\left(\mathrm{m}^{2}\right)\end{array}$ & $\begin{array}{l}\text { Stable } \\
(\%)\end{array}$ \\
\hline 4 & 67.70 & 100 & 67.70 & 100 & 32 & 56.74 & 56.39 & 100 & 0.54 & 2.65 & 6.7 & 32.92 \\
\hline 5 & 67.70 & 100 & 67.70 & 100 & 23.05 & 40.88 & 56.39 & 100 & 0 & 0 & 2.69 & 3.97 \\
\hline 6 & 63.67 & 94.05 & 67.70 & 100 & 7.06 & 12.50 & 56.39 & 100 & 0 & 0 & 2.69 & 3.97 \\
\hline 7 & 49.74 & 73.47 & 67.70 & 100 & 3.63 & 6.44 & 56.39 & 100 & 0 & 0 & 2.14 & 3.16 \\
\hline 8 & 30.08 & 44.43 & 67.70 & 100 & 1.46 & 2.59 & 52.78 & 93.60 & 0 & 0 & 1.6 & 2.36 \\
\hline 9 & 13.19 & 19.48 & 67.70 & 100 & 0 & 0 & 49.99 & 88.65 & 0 & 0 & 1.07 & 1.58 \\
\hline 10 & 3.16 & 4.67 & 67.70 & 100 & 0 & 0 & 47.62 & 84.45 & 0 & 0 & 0.54 & 0.80 \\
\hline 11 & 0 & 0 & 67.70 & 100 & 0 & 0 & 39.23 & 69.57 & 0 & 0 & 0.54 & 0.80 \\
\hline 12 & 0 & 0 & 67.70 & 100 & 0 & 0 & 26.58 & 47.14 & 0 & 0 & 0 & 0 \\
\hline 14 & 0 & 0 & 64.20 & 94.83 & 0 & 0 & 18.1 & 32.10 & 0 & 0 & 0 & 0 \\
\hline 16 & 0 & 0 & 60.83 & 89.85 & 0 & 0 & 15.12 & 26.81 & 0 & 0 & 0 & 0 \\
\hline 18 & 0 & 0 & 11.88 & 17.55 & 0 & 0 & 11.6 & 20.57 & 0 & 0 & 0 & 0 \\
\hline 20 & 0 & 0 & 1.03 & 1.52 & 0 & 0 & 9.27 & 16.44 & 0 & 0 & 0 & 0 \\
\hline 22 & 0 & 0 & 0 & 0 & 0 & 0 & 6.6 & 11.70 & 0 & 0 & 0 & 0 \\
\hline 24 & 0 & 0 & 0 & 0 & 0 & 0 & 2.87 & 5.09 & 0 & 0 & 0 & 0 \\
\hline 26 & 0 & 0 & 0 & 0 & 0 & 0 & 0 & 0 & 0 & 0 & 0 & 0 \\
\hline
\end{tabular}

Total stable area in square metres and stable area in percentage calculated with discharges between 4 and $26 \mathrm{~m}^{3} \mathrm{~s}^{-1}$ and two different grain size diameters $\left(d_{\mathrm{m}} \quad 20 \mathrm{~mm}\right.$ or $\left.d_{\mathrm{m}} \quad 50 \mathrm{~mm}\right)$ 


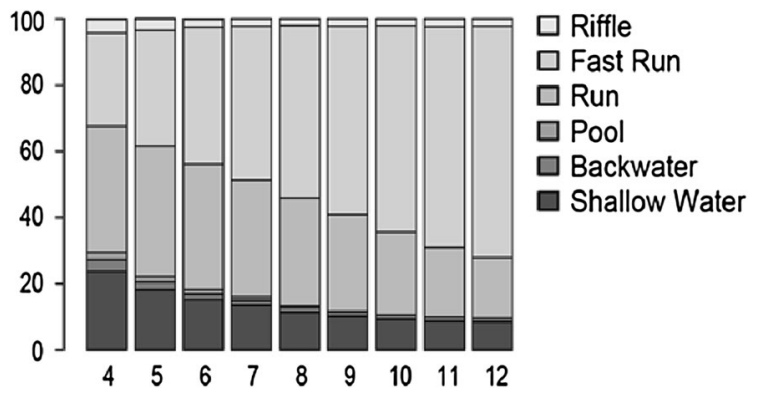

Fig. 9 Distribution of mesohabitat types in relation to the total wetted area of the three reaches calculated for a discharge range of $412 \mathrm{~m}^{3} \mathrm{~s}^{-1}$

the selected salmonid species. The relative mesohabitat distribution clearly changes over the discharge range of $412 \mathrm{~m}^{3} \mathrm{~s}^{-1}$ (Fig. 9). At low flows $\left(4 \mathrm{~m}^{3} \mathrm{~s}^{-1}\right.$ ), the three mesohabitat types, shallow water (24\%), fast run (28\%) and run (38\%), dominate. Run reaches its maximum expansion at a discharge of $5 \mathrm{~m}^{3} \mathrm{~s}^{-1}$. With further increasing discharge, the area covered by this habitat type starts to decrease to a minimum extent of $18 \%$ at $12 \mathrm{~m}^{3} \mathrm{~s}^{-1}$. Shallow water mesohabitats have their maximum extension at $4 \mathrm{~m}^{3} \mathrm{~s}^{-1}$. With increasing discharge, the total area of the shallow water mesohabitat becomes smaller. However, the decrease is especially strong between 4 and $8 \mathrm{~m}^{3} \mathrm{~s}^{-1}$, when the area shrinks to about half of its size at low flow. Between 9 and $12 \mathrm{~m}^{3} \mathrm{~s}^{-1}$, the area remains nearly the same, mostly due to the increase of total wetted area. As more parts in the riverbed overflow, larger areas with low water depth and nearly stagnant water can be found. Fast run mesohabitats increase in areal extent if discharge increases. From 4 to $12 \mathrm{~m}^{3} \mathrm{~s}^{-1}$ the area of fast run mesohabitats does more than double. Pool mesohabitats consist of deep water with low-flow velocity. Pools are the largest at a discharge of $4 \mathrm{~m}^{3} \mathrm{~s}^{-1}$ and almost disappear at the discharges of $11 \mathrm{~m}^{3} \mathrm{~s}^{-1}$. Backwaters and riffles peak both under low-flow conditions and are the smallest at discharge of 9 and $8 \mathrm{~m}^{3} \mathrm{~s}^{-1}$, respectively (Fig. 9).

\section{Mesohabitat distribution under summer low-flow conditions in the near and far future}

Only the climate scenario DMI ECHAM HIRHAM leads to predictions of increasing summer flow levels for the future, while the other nine scenarios result in decreasing flow levels (Table 4).
Thus, we can expect decreasing summer flow levels in future, and we will base our discussion on this notion.

Within the CTRL period, the total wetted area in Reach 1 is under summer low flow, on average $4,734 \mathrm{~m}^{2}$; the surface area of the same stretch would decrease to $4,427 \mathrm{~m}^{2}\left( \pm 158 \mathrm{~m}^{2}\right)$ in the near future and $4,220 \mathrm{~m}^{2}\left( \pm 180 \mathrm{~m}^{2}\right)$ in the far future. The mesohabitat distribution changes accordingly. The biggest change is predicted for fast runs and runs. While the relative area of fast runs is decreasing (CTRL period $77 \%$, near future mean $53 \%$, far future; mean $36 \%$ ), the area of runs is increasing (CTRL period $13 \%$, near future mean $31 \%$, far future mean $44 \%)$. The fraction of shallow water increases with the decreasing discharge (CTRL period $6.5 \%$, near future mean $8.3 \%$, Far Future mean 12\%), and so does the area of riffles (CTRL period $0.56 \%$, near future mean $4.44 \%$, far future mean $4.9 \%$ ). Slight changes appear for pools (CTRL period $0.79 \%$, near future mean $0.09 \%$, far future mean $0.03 \%$ ) and backwaters (CTRL period $2.0 \%$, near future mean $3.4 \%$, far future mean $3.6 \%$ ).

In Reach 2, the total wetted area during the CTRL period is $3,351 \mathrm{~m}^{2}$, calculated with the average discharge of the hydrologic/climatic scenarios; it would be reduced to $3,222 \pm 163 \mathrm{~m}^{2}$ in the near future and to $3,015 \pm 196 \mathrm{~m}^{2}$ in the far future (Table 4). However, the relative changes in mesohabitat composition are relatively small. Fast runs remain the most dominant habitat type (CTRL period 78\%, near future mean $73 \%$, far future mean $63 \%$ ), but the fractions of runs (CTRL period 13\%, near future mean $17 \%$, far future mean 24\%) and shallow waters (CTRL period $7.0 \%$, near future mean $8.0 \%$, far future mean $10 \%)$ expand. The changes in riffle (CTRL period $1.7 \%$, near future mean $1.9 \%$, far future mean $2.4 \%$ ) and backwaters (CTRL period $0.10 \%$, near future mean $0.08 \%$, far future mean $0.03 \%$ ) are small. The pool appears in the future scenarios (CTRL period $0.00 \%$, near future mean $0.16 \%$, far future mean $0.58 \%)$.

The total wetted area of Reach 3 decreases from $7,249 \mathrm{~m}^{2}$ to a mean of $7,045 \pm 327 \mathrm{~m}^{2}$ in the near future, and to a mean of $6,612 \pm 480 \mathrm{~m}^{2}$ in the far future (Table 4). The change of the mesohabitat distribution is comparable to Reach 1 . The fast runs decrease drastically (CTRL period $70 \%$, near future mean $61 \%$, far future mean $45 \%$ ), runs (CTRL period 
Table 4 Mesohabitat distribution in the three modelled river reaches under summer low flow conditions for the control period and the predictions of the different climate models

\begin{tabular}{|c|c|c|c|c|c|c|c|c|}
\hline Climate model & $\begin{array}{l}\text { Discharge } \\
\left(\mathrm{m}^{3} \mathrm{~s}^{-1}\right) \\
13.09\end{array}$ & $\begin{array}{l}\text { Shallow } \\
\text { water } \\
6.54\end{array}$ & Backwater & Pool & Run & $\begin{array}{l}\text { Fast run } \\
76.64\end{array}$ & Riffle & $\begin{array}{l}\text { Total wetted } \\
\text { area }\left(\mathrm{m}^{2}\right) \\
473386\end{array}$ \\
\hline Control period & 13.09 & & 2.04 & 0.19 & & & & \\
\hline \multicolumn{9}{|l|}{ Reach 1} \\
\hline \multirow[t]{2}{*}{ HC HadCM3Q0 HadRM3Q0 } & NF; 5.32 & 14.16 & 3.76 & 0.01 & 54.93 & 21.16 & 5.98 & $4,041.56$ \\
\hline & FF; 4.45 & 20.64 & 4.03 & 0.02 & 52.71 & 15.56 & 7.03 & $3,979.58$ \\
\hline \multirow[t]{2}{*}{ ETHZ HadCM3Q0 CLM } & NF; 8.51 & 9.03 & 3.44 & 0.02 & 40.75 & 42.8 & 3.96 & $4,312.34$ \\
\hline & FF; 5.08 & 15.51 & 3.84 & 0.01 & 54.64 & 19.67 & 6.32 & $4,020.79$ \\
\hline \multirow[t]{2}{*}{ CNRM ARPEGE ALADIN } & NF; 9.29 & 8.72 & 3.41 & 0.02 & 35.9 & 47.7 & 4.24 & $4,367.31$ \\
\hline & FF; 4.96 & 18.58 & 3.92 & 0.01 & 53.43 & 17.22 & 6.84 & $3,999.11$ \\
\hline \multirow[t]{2}{*}{ MPI ECHAM REMO } & NF; 11.06 & 7.26 & 3.38 & 0.08 & 28.57 & 56.07 & 4.64 & $4,443.29$ \\
\hline & FF; 7.05 & 9.45 & 3.55 & 0.02 & 50.17 & 32.76 & 4.05 & $4,156.97$ \\
\hline \multirow[t]{2}{*}{ DMI ECHAM HIRHAM } & NF; 11.07 & 7.37 & 3.35 & 0.07 & 28.4 & 55.93 & 4.88 & $4,440.99$ \\
\hline & FF; 11.77 & 7.59 & 3.3 & 0.1 & 25.98 & 58.53 & 4.51 & $4,502.52$ \\
\hline \multirow[t]{2}{*}{ SMHI ECHAM RCA } & NF; 11.61 & 7.69 & 3.34 & 0.09 & 26.54 & 57.88 & 4.46 & $4,497.06$ \\
\hline & FF; 7.39 & 9.56 & 3.57 & 0.02 & 47.79 & 35.47 & 3.59 & $4,213.92$ \\
\hline \multirow[t]{2}{*}{ ICTP ECHAM REGCM } & NF; 11.97 & 7.48 & 3.28 & 0.11 & 25.44 & 59.32 & 4.37 & $4,507.63$ \\
\hline & FF; 9.09 & 8.96 & 3.43 & 0.03 & 36.64 & 46.66 & 4.27 & $4,353.51$ \\
\hline \multirow[t]{2}{*}{ SMHI HadCM3Q3 RCA } & NF; 12.87 & 7.34 & 3.27 & 0.13 & 23.27 & 62.1 & 3.91 & $4,544.86$ \\
\hline & FF; 9.02 & 8.92 & 3.45 & 0.02 & 37.19 & 46.24 & 4.18 & $4,347.41$ \\
\hline \multirow[t]{2}{*}{ KNMI ECHAM RACMO } & NF; 13.0 & 7.2 & 3.28 & 0.16 & 22.8 & 62.59 & 3.96 & $4,546.87$ \\
\hline & FF; 7.68 & 9.73 & 3.52 & 0.02 & 45.95 & 37.07 & 3.71 & $4,243.19$ \\
\hline \multirow[t]{2}{*}{ SMHI BCM RCA } & NF; 13.57 & 6.99 & 3.14 & 0.17 & 21.51 & 64.19 & 4 & $4,567.84$ \\
\hline & FF; 9.61 & 8.57 & 3.38 & 0.05 & 34.27 & 49.52 & 4.21 & $4,384.86$ \\
\hline Control period & 11.87 & 6.96 & 0.10 & 0 & 12.85 & 78.39 & 1.71 & $3,351.33$ \\
\hline \multicolumn{9}{|l|}{ Reach 2} \\
\hline \multirow[t]{2}{*}{ HC HadCM3Q0 HadRM3Q0 } & $\mathrm{NF} ; 4.95$ & 11.72 & 0 & 1.31 & 29.91 & 53.8 & 3.26 & $2,858.65$ \\
\hline & FF; 4.1 & 13.71 & 0 & 1.34 & 32.33 & 48.74 & 3.88 & $2,726.75$ \\
\hline \multirow[t]{2}{*}{ ETHZ HadCM3Q0 CLM } & NF; 7.8 & 8.93 & 0.04 & 0.09 & 21.11 & 68.14 & 1.69 & $3,106.77$ \\
\hline & FF; 4.65 & 12.38 & 0 & 1.3 & 31.01 & 51.67 & 3.64 & $2,816.73$ \\
\hline \multirow[t]{2}{*}{ CNRM ARPEGE ALADIN } & NF; 8.44 & 8.48 & 0.04 & 0.04 & 19.36 & 70.34 & 1.76 & $3,149.8$ \\
\hline & FF; 4.38 & 13.29 & 0 & 1.28 & 31.53 & 50 & 3.89 & $2,777.74$ \\
\hline \multirow[t]{2}{*}{ MPI ECHAM REMO } & NF; 10.13 & 7.49 & 0.1 & 0 & 15.21 & 75.56 & 1.64 & $3,255.26$ \\
\hline & FF; 6.51 & 10.6 & 0 & 0.78 & 24.15 & 62.59 & 1.87 & $3,026.81$ \\
\hline \multirow[t]{2}{*}{ DMI ECHAM HIRHAM } & NF; 10.18 & 7.51 & 0.1 & 0 & 15.12 & 75.6 & 1.67 & $3,258.89$ \\
\hline & FF; 10.6 & 7.22 & 0.1 & 0 & 14.47 & 76.41 & 1.8 & $3,282.97$ \\
\hline \multirow[t]{2}{*}{ SMHI ECHAM RCA } & NF; 10.63 & 6.83 & 0.1 & 0 & 14.54 & 76.74 & 1.78 & $3,272.86$ \\
\hline & FF; 6.81 & 8.95 & 0 & 0.56 & 23.73 & 65.0 & 1.76 & $3,005.89$ \\
\hline \multirow[t]{2}{*}{ ICTP ECHAM REGCM } & NF; 10.92 & 7.3 & 0.12 & 0 & 14.21 & 76.58 & 1.79 & $3,307.77$ \\
\hline & FF; 8.27 & 8.72 & 0.04 & 0.04 & 19.47 & 70.13 & 1.6 & $3,138.09$ \\
\hline \multirow[t]{2}{*}{ SMHI HadCM3Q3 RCA } & $\mathrm{NF} ; 11.71$ & 6.89 & 0.1 & 0 & 13.15 & 78.12 & 1.74 & $3,342.34$ \\
\hline & FF; 8.13 & 8.79 & 0.04 & 0.03 & 19.76 & 69.74 & 1.64 & $3,126.06$ \\
\hline \multirow[t]{2}{*}{ KNMI ECHAM RACMO } & NF; 11.84 & 6.95 & 0.1 & 0 & 12.9 & 78.39 & 1.66 & $3,350.4$ \\
\hline & FF; 7.06 & 9.8 & 0.01 & 0.44 & 22.67 & 65.35 & 1.72 & $3,057.14$ \\
\hline
\end{tabular}


Table 4 continued

\begin{tabular}{|c|c|c|c|c|c|c|c|c|}
\hline Control period & 11.87 & 6.96 & 0.10 & 0 & 12.85 & 78.39 & 1.71 & $3,351.33$ \\
\hline \multirow[t]{2}{*}{ SMHI BCM RCA } & NF; 12.14 & 6.98 & 0.1 & 0 & 12.62 & 78.68 & 1.61 & $3,365.63$ \\
\hline & FF; 8.76 & 8.35 & 0.04 & 0.02 & 18.75 & 71.17 & 1.68 & $3,178.58$ \\
\hline Control period & 11.47 & 10.12 & 0.47 & 0.02 & 18.09 & 70.30 & 0.99 & $7,249.26$ \\
\hline \multicolumn{9}{|l|}{ Reach 3} \\
\hline \multirow[t]{2}{*}{ HC HadCM3Q0 HadRM3Q0 } & NF; 4.83 & 1.79 & 35.45 & 34.04 & 3.13 & 2.57 & 23.01 & $6,164.32$ \\
\hline & FF; 3.98 & 2.03 & 29.44 & 31.93 & 3.83 & 4.49 & 28.28 & $5,856.37$ \\
\hline \multirow[t]{2}{*}{ ETHZ HadCM3Q0 CLM } & NF; 7.56 & 1.26 & 49.84 & 32.13 & 1.19 & 0.72 & 14.86 & $6,931.62$ \\
\hline & FF; 4.51 & 1.82 & 33.6 & 32.57 & 3.48 & 3.53 & 25.01 & $6,057.92$ \\
\hline \multirow[t]{2}{*}{ CNRM ARPEGE ALADIN } & NF; 8.18 & 1.15 & 53.24 & 31.41 & 0.54 & 0.64 & 13.03 & $6,998.06$ \\
\hline & FF; 4.28 & 1.91 & 31.84 & 32.95 & 3.56 & 3.92 & 25.82 & $5,968.23$ \\
\hline \multirow[t]{2}{*}{ MPI ECHAM REMO } & NF; 9.82 & 1.06 & 61.94 & 25.34 & 0.08 & 0.51 & 11.07 & $7,128.88$ \\
\hline & FF; 6.33 & 1.28 & 44.36 & 31.86 & 2.63 & 1 & 18.88 & $6,606.17$ \\
\hline \multirow[t]{2}{*}{ DMI ECHAM HIRHAM } & NF; 9.87 & 1.07 & 62.22 & 25.14 & 0.07 & 0.51 & 11 & $7,133.69$ \\
\hline & FF; 10.24 & 1.07 & 64.42 & 23.34 & 0.06 & 0.49 & 10.62 & $7,154.12$ \\
\hline \multirow[t]{2}{*}{ SMHI ECHAM RCA } & NF; 10.31 & 1.09 & 64.79 & 23.02 & 0.05 & 0.49 & 10.56 & $7,158.37$ \\
\hline & FF; 6.62 & 1.4 & 45.52 & 31.8 & 2.39 & 0.86 & 18.03 & $6,688.09$ \\
\hline \multirow[t]{2}{*}{ ICTP ECHAM REGCM } & NF; 10.58 & 1.09 & 66.62 & 21.35 & 0.04 & 0.48 & 10.42 & $7,183.98$ \\
\hline & FF; 8.01 & 1.16 & 52.4 & 31.58 & 0.73 & 0.65 & 13.47 & $6,984.8$ \\
\hline \multirow[t]{2}{*}{ SMHI HadCM3Q3 RCA } & NF; 11.34 & 1.1 & 69.81 & 18.41 & 0.02 & 0.47 & 10.19 & $7,241.09$ \\
\hline & FF; 7.85 & 1.18 & 51.74 & 31.73 & 0.95 & 0.67 & 13.73 & $6,963.22$ \\
\hline \multirow[t]{2}{*}{ KNMI ECHAM RACMO } & NF; 11.46 & 0.99 & 70.28 & 18.17 & 0.02 & 0.47 & 10.07 & $7,248.45$ \\
\hline & FF; 6.86 & 1.34 & 46.17 & 31.43 & 2.05 & 0.83 & 18.17 & $6,814.23$ \\
\hline \multirow[t]{2}{*}{ SMHI BCM RCA } & NF; 11.71 & 1.08 & 71.38 & 17.05 & 0.02 & 0.48 & 9.99 & 7,263 \\
\hline & FF; 8.49 & 1.23 & 54.6 & 30.49 & 0.36 & 0.61 & 12.71 & $7,030.83$ \\
\hline
\end{tabular}

Control period 19802009 and climate models with an $\mathrm{AB} 1 \mathrm{CO}_{2}$ output; for the near future 20212050 (NF) and the far future 20702099 (FF), mesohabitat distribution in percentage of total wetted area and total wetted area in square metres of each river reach

$18 \%$, near future mean $25 \%$, far future mean $31 \%$ ) and shallow water (CTRL period $10 \%$, near future mean $12 \%$, far future mean $18 \%$ ) become more dominant. The less dominant habitats increase, and the most expansion is found in the pool (CTRL period $0.02 \%$, near future mean $0.51 \%$, far future mean $2.0 \%$ ) compared to riffle (CTRL period $0.99 \%$, near future mean $1.2 \%$, far future mean $1.4 \%$ ) and backwaters (CTRL period $0.47 \%$, near future mean $0.73 \%$, far future mean $1.7 \%$ ).

\section{Ecological relevance of mesohabitat modelling}

The electrofishing survey across different types of mesohabitats showed a clear pattern of usability for the different age classes (Fig. 10). The YOY clearly preferred shallow water mesohabitats. Within these habitats, the density was more than twice as high as it was in the next most frequently used backwater mesohabitats. In runs and riffles, YOY could still be found, whereas fast runs and pools were unused (Fig. 10a). A different pattern can be seen in subadult and adult classes. Both were found in all of the six habitat types, showing the highest density in backwaters and riffles. While the subadult class was also found in runs, fast runs and shallow water, they were least frequent in pools, and adults used fast runs, pools, and runs but rarely shallow water (Fig. 10b, c).

Combining the results of future summer low-flow scenarios and habitat suitability, we find a habitat area increase for YOY. This age class was mostly found in shallow water mesohabitats, which increases with a decreasing water discharge. The shallow water area in the three test reaches during the CTRL period is 

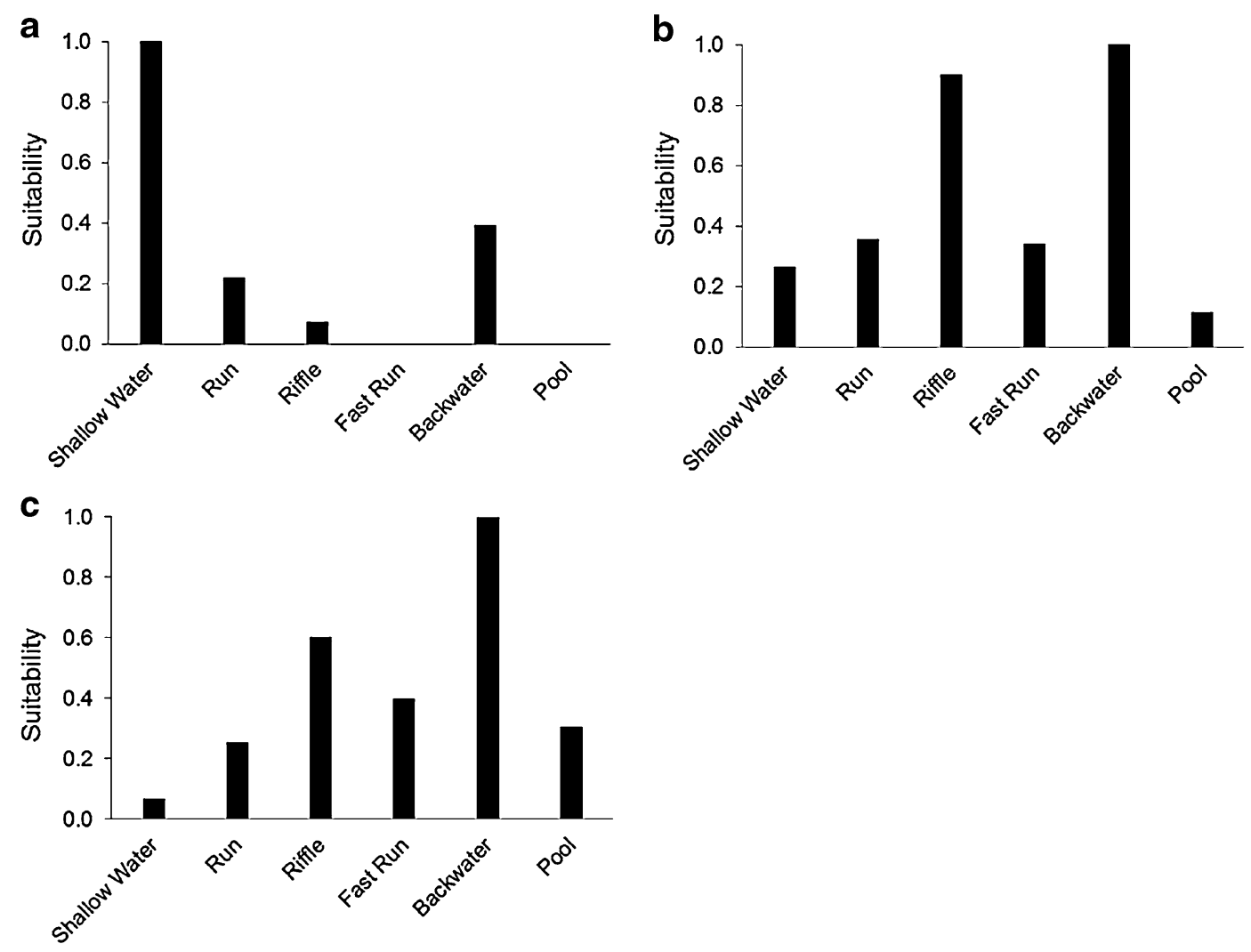

Fig. 10 Mesohabitat suitability for a YOY, b subadult and $\mathbf{c}$ adult. Usability index was calculated with the relative frequency of density, normalized by taking the highest value as one

$1,276 \mathrm{~m}^{2}$. The near future shows an average increase up to $1,485 \mathrm{~m}^{2}$, and for the far future, the shallow water surface is $1,992 \mathrm{~m}^{2}$. This means an increase of the most used habitat type of the YOY of $36 \%$.

\section{Discussion}

We used an interdisciplinary approach to investigate the influence of climate change on the early life stages of brown trout. Our results show different outcomes for different stages of the reproductive cycle and at different times into the future, with especially pronounced impacts in the far future scenarios.

Bedload transport and morphodynamics

Bedload transport predictions are often associated with a large uncertainty (Gomez \& Church, 1989; Rickenmann, 2001; Barry et al., 2004; Nitsche et al., 2011). Therefore, we focused our analysis on relative comparisons of the results of different simulation runs between the CTRL period and the future situation. We did not interpret the simulation results in terms of absolute values, but rather in terms of relative changes compared to other simulation results to derive general trends. However, it is important to consider that all predictions by the bedload routing model sedFlow are averaged for each simulation leg of the stream, with leg length varying between $50 \mathrm{~m}$ and $200 \mathrm{~m}$. Variation within each leg cannot be resolved, and locally much higher or lower values can be expected.

Bedload transport simulations were performed for a total river length of $20 \mathrm{~km}$ including about 150 legs. These legs represent a considerable range of channel slopes, grain size distributions and shear stresses, and all these parameters evolve over time during the simulation runs. On the local scale, spatially and temporally variable bed morphologies and grain sizes may induce variations in local bed slopes and shear stress covering a similar range to that of the reachscale simulations. We may therefore speculate that the general trends identified from the bedload transport 
simulations at the reach scale may, at least in part, also be representative of possible changes expected to occur at local scales. Along the same lines, the minimum Shields value of 0.06 used in the sedFlow simulations at the reach scale is not consistent with the critical Shields value of 0.047 of Eq. (3) used for the local scale analysis with the MEM model. However, it should be noted that the sedFlow simulations were performed in one dimension and included a calibration with bedload transport observations, while the MEM model uses a two-dimensional approach on a local scale. In reality, one may expect Shields values to vary both in space (Kirchner et al., 1990) and in time (Turowski et al., 2011), and thus the use of different critical Shields values appears to be acceptable.

The rainfall runoff simulations of the CCHydro (Bernhard \& Zappa, 2012) project predict an increase in winter discharges (Fig. 4). This prediction is the main driving factor for the simulated trends of increasing magnitudes and durations of winter scour. Across virtually all years and profiles in which scouring occurs, we observed an increase in erosion depth. The highest erosion depths tend to occur later in winter. This means that erosion occurs over longer time periods. This is not surprising, as the increased discharges will stay above the threshold for bedload transport and thus erode for a longer time in the future than in the CTRL period. Further challenges to the fish fauna for finding suitable spawning grounds may be presented by the sharper transition between stable and unstable regions predicted for the future, which implies sharper boundaries of potential spawning grounds.

Most previous studies of the impact of climate change on sediment transport either focused on lowland rivers (Verhaar et al., 2010, 2011) or did not report erosion and deposition resolved for different seasons (Gomez et al., 2009). These studies are therefore of limited value for our purposes. Coulthard et al. (2012) predicted a future increase in sediment transport, especially during the winter months, for the Swale River (United Kingdom). This is in qualitative agreement with our prediction of an increase in winter erosion depths for the river Kleine Emme. Goode et al. (2013) assessed the potential future impacts of changing sediment transport on salmonid habitat on the catchment scale in the Middle Fork Salmon River (USA). They predict climate change to increase scour magnitude, which will lead to a smaller breeding success, especially for smaller-bodied fall spawners. Thus, the results of their large-scale study are in line with our detailed assessment of the Kleine Emme.

Spawning and incubation phase

In a study of the alpine river Ybbs, a tributary of the Danube, Unfer et al. (2011) found high survival of YOY if the discharge during incubation time was lower than $30 \mathrm{~m}^{3} \mathrm{~s}^{-1}$, which compares to an annual mean high flow at the study site of $57 \mathrm{~m}^{3} \mathrm{~s}^{-1}$. Higher water flow led to substantial sediment transport, resulting in egg and fry damage due to scouring. As a result, only a small proportion of YOY in the population was found the following autumn. On the other hand Unfer et al. (2011) found a positive correlation between reproductive success and highflow events, if the flow events happened during spawning time. This can be explained by a rearrangement of suitable spawning ground (Unfer et al., 2011) and a washout of deleterious fine sediment (Zeh \& Dönni, 1994) before the incubation actually starts. For the Kleine Emme, the discharge during spawning and incubation time might be increased by about $2 \mathrm{~m}^{3} \mathrm{~s}^{-1}$ in the near future and by about $3 \mathrm{~m}^{3} \mathrm{~s}^{-1}$ in the far future (Fig. 4). As a direct consequence, the lowest bed elevation will occur later in the year, and scouring depths will increase. In our simulations, the entire spawning ground is $100 \%$ unstable at discharges smaller than $26 \mathrm{~m}^{3} \mathrm{~s}^{-1}$ (Table 3). Peak flows of this magnitude presently occur on average about six times during the incubation time (BAFU, 2013) but will most likely occur more often in the future. In our scenario, it is therefore likely that the stable spawning habitat areas might decrease in the future, and erosion depths will more frequently exceed the average egg burial depth.

\section{Parr phase}

Another critical period in the life cycle of salmonids occurs when juvenile fish emerge from the gravel and establish their feeding territories. Considering the average water temperature during incubation time of about $5^{\circ} \mathrm{C}$ in the Kleine Emme, this happens in the study reach during April and May. Feeding habitats are usually in the direct surroundings of the redd, and after settling, the fish do not typically disperse till autumn 
(Egglishaw \& Shackley, 1980; Rimmer et al., 1983, 1984; Armstrong et al., 1994). Habitat quality near spawning grounds is therefore crucial for the development of juveniles. Typically, the flow velocity near the snouts of brown trout parr smaller than $7 \mathrm{~cm}$ is between 0 and $0.1 \mathrm{~ms}^{-1}$, and they can rarely be found in parts of the stream with flow velocities exceeding $0.5 \mathrm{~ms}^{-1}$ (Heggenes et al., 1999). The preferred depth of parr is between 0.05 and $0.3 \mathrm{~m}$ and both, preferred depth and flow velocity, increase with fish size (Greenberg, 1994; Maki-Petays et al., 1997; Riley et al., 2009). Our fishing survey at the Kleine Emme River based on modelled mesohabitats confirmed these values from the literature. We found a clear age class distribution. The YOY were most abundant in shallow waters (flow velocity $<0.2 \mathrm{~ms}^{-1}$, flow depth $<0.4 \mathrm{~m}$ ). Subadult and adult fish showed a more diverse distribution, with increased use of high-energy habitats like riffles and fast runs. Both of these two age classes were mostly found in backwaters, which are by definition low energetic habitats. However, an exclusive focus on depth and flow velocity does not do justice to the whole complexity of a habitat. Other major parameters like substrate, vegetation cover, competition or predation can strongly influence the distribution of fish in a stream. On the other hand, the importance of shallow, slow-flowing water for recruitment, and the movement into deeper parts of a river with increasing growth has been shown in many other studies (e.g. Bardonnet \& Heland, 1994; Crisp, 1996; Heggenes, 1996), and these findings are consistent with our results. We furthermore predict more pronounced summer low flows, which can lead to higher habitat diversity, especially due to an increase in shallow water habitats (see Hauer et al., 2012). Such an increase in suitable habitat area could lead to a higher carrying capacity of the habitat of brown trout parr during early summer and reduce selfthinning effects for early free living life stages (Elliot, 1994; Milner et al., 2003).

\section{Conclusions and possible mitigation measures}

Predictions of how salmonids will adapt to a changing environment driven by climate change are difficult to make due to the complex interplay of many factors. For example, changing temperature may influence the onset of spawning (Wedekind \& Kung, 2010), sex determination (Craig et al., 1996; Moeliker, 2001;
Baroiller et al., 2009), fry development (Elliot, 1994), prey availability (Crozier et al., 2008) or diseases (Wedekind et al., 2010). Seasonal variation in discharge also relates to the initiation of migration (Banks, 1969; Jonsson, 1991) and spawning (LobonCervia, 2004). We have focused on the effect of climate change on discharge and bedload transport during the incubation time and the availability of physical habitat later in the year. From this point of view, the results indicate two different and important outcomes for different life stages. While future conditions during incubation time may become less favourable for brown trout survival due to higher and more frequent floods in the winter season, it is possible that conditions later in the year become more favourable. As was suggested by Goode et al. (2013) and Hauer et al. (2012), predicted outcomes on early brown trout development depend strongly on river morphology and the flow regime. In general, a natural riverbed has the ability to buffer the power of a flood and maintain habitat diversity. This, on the other hand, is not true for embanked and artificially channelized parts of a river. Here, water level increases with increasing discharge up to bankfull stage and beyond. The corresponding increases in stream power can lead to high erosion and hence a predominance of high-energy habitats. Depending on timing of the flooding, this will lead to egg scour and/or displacement of juvenile fish. Our results indicate that in the future, small tributaries may become more important for spawning, due to their lower discharge and flood power compared to the main river stem. The fact that many smaller tributaries in Switzerland and elsewhere are blocked by barriers (e.g. Yamamoto et al., 2004; Raeymaekers et al., 2009; ZehWeissmann et al., 2009) that will have to be removed if fish are to be able access these areas. We conclude that the restoration of lateral and longitudinal connectivity through the removal of artificial embankments and tributary weirs should be a high priority of rehabilitation works in these systems to maintain essential spawning habitat under future climates.

Acknowledgements The investigations related to the fish habitat and the bedload transport modelling were supported by a Grant of the Swiss National Science Foundation (NRP 61 Project SEDRIVER Contract No. 406140 125975/1) to DR, AP and JMT. The hydrological impact study has been supported by a Grant from the Swiss Federal Office for Environment (CCHydro). We are indebted to the EU FP6 Project ENSEMBLES (Contract 505539) and MeteoSwiss for 
providing us access to all necessary data. Many thanks go to Reto Haas for support on GIS and in the field. We are also grateful for field support to Salome Mwaiko, Cristina Hertz and Brigitte German. Furthermore, we thank Catherine E. Wagner for reviewing the manuscript.

\section{References}

Armstrong, J. D., P. E. Shackley \& R. Gardiner, 1994. Redis tribution of juvenile salmonid fishes after localized cata strophic depletion. Journal of Fish Biology 45: 10271039.

Badoux, M., A. Peter, D. Rickenmann, J. Junker, F.U.M. Hei mann, M. Zappa, J.M. Turowski, 2014. Geschiebetransport und Forellenhabitate in Gebirgsflüssen der Schweiz: mögliche Auswirkungen der Klimaänderung. Wasser En ergie Luft 106: 200209.

Bundesamt für Umwelt BAFU, 2005. Aktualisierte Pardé Koeffizienten für die Abflussregimetypen nach Aschwan den und Weingartner. Internes Papier, Bundesamt für Umwelt (BAFU), Bern.

Bundesamt für Umwelt BAFU (Hrsg.), 2012. Auswirkungen der Klimaänderung auf Wasserressourcen und Gewässer. Synthesebericht zum Projekt «Klimaänderung und $\mathrm{Hy}$ drologie in der Schweiz» (CCHydro). Bundesamt für Umwelt, Bern. Umwelt Wissen Nr. 1217: 76.

Bundesamt für Umwelt BAFU, 2013. http://www.hydrodaten. admin.ch/de/index.html?lang=de.

Banks, J. W., 1969. A review of the literature on the upstream migration of adult salmonids. Journal of Fish Biology 1: 85136.

Bardonnet, A. \& M. Heland, 1994. The influence of potential predators on the habitat preferences of emerging brown trout. Journal of Fish Biology 45: 131142.

Baroiller, J. F., H. D'Cotta \& E. Saillant, 2009. Environmental effects on fish sex determination and differentiation. Sex ual Development 3: 118135.

Barry, J. J., J. M. Buffington \& J. G. King, 2004. A general power equation for predicting bed load transport rates in gravel bed rivers. Water Resources Research 40: W10401.

Bathurst, J., J. Ewen, G. Parkin, P. O'Connell \& J. Cooper, 2004. Validation of catchment models for predicting land use and climate change impacts. 3 . Blind validation for internal and outlet responses. Journal of Hydrology 287: 7494.

Begert, M., T. Schlegel \& W. Kirchhofer, 2005. Homogeneous temperature and precipitation series of Switzerland from 1864 to 2000. International Journal of Climatology 25: 6580.

Bernhard, L. \& M. Zappa, 2012. Klimaänderung und natürlicher Wasserhaushalt der Grosseinzugsgebiete der Schweiz. Schlussbericht zum Projekt Klimaänderung und Hydrolo gie in der Schweiz (CCHydro). Birmensdorf, Eidg. Fors chungsanstalt WSL.

Birsan, M. V., P. Molnar, P. Burlando \& M. Pfaundler, 2005. Streamflow trends in Switzerland. Journal of Hydrology 314: 312329.

Bisson, P. A., J. L. Nielsen, R. A. Palmason \& L. E. Grove, 1981. A system of naming habitat types in small streams, with examples of habitat utilization by salmonids during low streamflow. Symposium on acquisition and utilization of aquatic habitat inventory information.

Bosshard, T., S. Kotlarski, T. Even \& C. Schär, 2011. Spectral representation of the annual cycle in the climate change signal. Hydrological and Earth System Sciences 15: 27772788.

Brunetti, M., M. Maugeri, T. Nanni, I. Auer, R. Bohm \& W. Schöner, 2006. Precipitation variability and changes in the greater Alpine region over the 18002003 period. Journal of Geophysical Research Atmospheres 111 (D11).

Chiari, M., K. Friedl \& D. Rickenmann, 2010. A one dimen sional bedload transport model for steep slopes. Journal of Hydraulic Research 48: 152160.

Coulthard, T. J., J. Ramirez, H. J. Fowler \& V. Glenis, 2012. Using the UKCP09 probabilistic scenarios to model the amplified impact of climate change on drainage basin sediment yield. Hydrological Earth System Sciences 16: 44014416.

Craig, J. K., C. J. Foote \& C. C. Wood, 1996. Evidence for temperature dependent sex determination in sockeye sal mon (Oncorhynchus nerka). Canadian Journal of Fisheries and Aquatic Sciences 53: 141147.

Crisp, D. T., 1989. Use of artificial eggs in studies of washout depth and drift distance for salmonid eggs. Hydrobiologia 178: 155163 .

Crisp, D. T., 1996. Environmental requirements of common riverine European salmonid fish species in fresh water with particular reference to physical and chemical aspects. Hydrobiologia 323: 201221.

Crozier, L. G., A. P. Hendry, P. W. Lawson, T. P. Quinn, N. J. Mantua, J. Battin, R. G. Shaw \& R. B. Huey, 2008. Potential responses to climate change in organisms with complex life histories: evolution and plasticity in Pacific salmon. Evolutionary Applications 1: 252270.

Diodato, N., E. W. N. Støren, G. Bellocchi \& A. Nesje, 2013. Modelling sediment load in a glacial meltwater stream in western Norway. Journal of Hydrology 486: 343350.

Egglishaw, H. J. \& P. E. Shackley, 1980. Survival and growth of salmon, Salmo salar (L.), planted in a Scottish stream. Journal of Fish Biology 16: 565584.

Elliott, J. M., 1984. Numerical changes and population regula tion in young migratory trout Salmo trutta in a Lake Dis trict stream, 1966 83. Journal of Animal Ecology 53: 327350 .

Elliott, J. M., 1994. Quantitative Ecology and the Brown Trout. Oxford University press Inc., New York.

Elliott, A. H., F. Oehler, J. Schmidt \& J. C. Ekanayake, 2012. Sediment modelling with fine temporal and spatial reso lution for a hilly catchment. Hydrological Processes 26: 36453660 .

Fehr, R., 1987. A method for sampling very coarse sediments in order to reduce scale effects in movable bed models. Pro ceedings of IAHR Symposium on Scale Effects in Mod elling Sediment Transport Phenomena, Toronto, Canada, August 1986: 383397.

French, J. R., 2003. Airborne LiDAR in support of geomor phological and hydraulic modelling. Earth Surface Pro cesses and Landforms 28: 321335.

Frissell, C. A., W. J. Liss, C. E. Warren \& M. D. Hurley, 1986. A hierarchical framework for stream habitat classification 
viewing streams in a watershed context. Environmental Management 10: 199214.

Gleick, P. H., 1986. Methods for evaluating the regional hydrologic impacts of global climatic changes. Journal of Hydrology 88: 97116.

Gomez, B. \& M. Church, 1989. An assessment of bed load sediment transport formulas for gravel bed rivers. Water Resources Research 25: 11611186.

Gomez, B., Y. Cui, A. J. Kettner, D. H. Peacock \& J. P. M. Syvitski, 2009. Simulating changes to the sediment trans port regime of the Waipaoa River, New Zealand, driven by climate change in the twenty first century. Global Plane tary Change 67: 53166.

Goode, J. R., J. M. Buffington, D. Tonina, D. J. Isaak, R. F. Thurow, S. Wenger, D. Nagel, C. Luce, D. Tetzlaff \& C. Soulsby, 2013. Potential effects of climate change on streambed scour and risks to salmonid survival in snow dominated mountain basins. Hydrological Processes 27: 750765.

Graham, L. P., J. Andreasson \& B. Carlsson, 2007. Assessing climate change impacts on hydrology from an ensemble of regional climate models, model scales and linking methods a case study on the Lule River basin. Climatic Change 81(Suppl. 1): 293307.

Greenberg, L. A., 1994. Effects of predation, trout density and discharge on habitat use by brown trout, Salmo trutta, in artificial streams. Freshwater Biology 32: 111.

Grost, R. T., W. A. Hubert \& T. A. Wesche, 1990. Redd site selection by brown trout in Douglas Creek, Wyoming. Journal of Freshwater Ecology 5: 365371.

Hauer, C., G. Mandlburger \& H. Habersack, 2009. Hydrauli cally related hydro morphological units: description based on a new conceptual mesohabitat evaluation model (MEM) using LiDAR data as geometric input. River Research Application 25: 2947.

Hauer, C., G. Unfer, H. Holzmann, S. Schmutz \& H. Habersack, 2012. The impact of discharge change on physical instream habitats and its response to river morphology. Climate Change 116: 827850.

Heggenes, J., 1996. Habitat selection by brown trout (Salmo trutta) and young Atlantic salmon ( $S$. salar) in streams: static and dynamic hydraulic modelling. Regulated Rivers: Research and Management 12: 155169.

Heggenes, J., J. L. Bagliniere \& R. A. Cunjak, 1999. Spatial niche variability for young Atlantic salmon (Salmo salar) and brown trout $(S$. trutta) in heterogeneous streams. Ecology of Freshwater Fish 8: 121.

Heimann, F. U. M., D. Rickenmann, J. M. Turowski \& J. W. Kirchner, 2014a. sedFlow an efficient tool for simu lating bedload transport, bed roughness, and longitudinal profile evolution in mountain streams. Earth Surface Dynamics Discussion 2: 733772.

Heimann, F. U. M., D. Rickenmann, D. Böckli, M. Badoux, J. M. Turowski \& J. W. Kirchner, 2014b. Recalculation of bedload transport observations in Swiss mountain rivers using the model sedFlow. Earth Surface Dynamics Dis cussion 2: 773822.

Horton, P., B. Schaefli, A. Mezghani, B. Hingray \& A. Musy, 2006. Assessment of climate change impacts on alpine discharge regimes with climate model uncertainty. Hydrological Processes 20: 20912109.
Jager, H. I., W. Van Winkle \& B. D. Holcomb, 1999. Would hydrologic climate changes in Sierra Nevada streams influence trout persistence? Transactions of the American Fisheries Society 128: 222240.

Jasper, K., P. Calanca, D. Gyalistras \& J. Fuhrer, 2004. Dif ferential impacts of climate change on the hydrology of two alpine river basins. Climate Research 26: 113129.

Jonsson, N., 1991. Influence of water flow, water temperature and light on fish migration in rivers. Nordic Journal of Freshwater Research 66: 2035.

Jonsson, B. \& N. Jonsson, 2011. Habitat use. In Ecology of Atlantic Salmon and Brown Trout: Habitat as a Template for Life Histories, Vol. 33. Springer, New York: 67135.

Keeley, E. R. \& J. W. A. Grant, 1995. Allometric and envi ronmental correlates of territory size in juvenile atlantic salmon (Salmo salar). Canadian Journal of Fishery and Aquatic Sciences 52: 186196.

Kirchner, J. W., W. E. Dietrich, F. Iseya \& H. Ikeda, 1990. The variability of critical shear stress, friction angle, and grain protrusion in water worked sediments. Sedimentology 37: 647672.

Kobierska, F., T. Jonas, J. Magnusson, M. Zappa, M. Bavay \& S. M. Bernasconi, 2013. Future runoff from a partly glacier ized watershed in Central Switzerland: a 2 model approach. Advances in Water Resources 55: 204214.

Kondolf, G. M. \& M. G. Wolman, 1993. The sizes of salmonid spawning gravels. Water Resource Research 29: 22752285.

Köplin, N., B. Schädler, D. Viviroli \& R. Weingartner, 2010. How does climate change affect mesoscale catchments in Switzerland? A framework for a comprehensive assess ment. Advances in Geosciences 27: 111119.

Lamb, M. P., W. E. Dietrich \& J. G. Venditti, 2008. Is the critical Shields stress for incipient sediment motion dependent on channel bed slope? Journal of Geophysical Research 113(20): F02008.

Layzell, A. L., M. C. Eppes, B. G. Johnson \& J. A. Diemer, 2012. Post glacial range of variability in the Conejos River Valley, southern Colorado, USA: fluvial response to cli mate change and sediment supply. Earth Surface Processes Landforms 37: 11891202.

Lobon Cervia, J., 2004. Discharge dependent covariation pat terns in the population dynamics of brown trout (Salmo trutta) within a Cantabrian river drainage. Canadian Jour nal of Fisheries and Aquatic Sciences 61: 19291939.

Maki Petays, A., T. Muotka, A. Huusko, P. Tikkanen \& P. Kreivi, 1997. Seasonal changes in habitat use and prefer ence by juvenile brown trout, Salmo trutta, in a northern boreal river. Canadian Journal of Fisheries and Aquatic Sciences 54: 520530.

Meyer Peter, E. \& R. Müller, 1948. Formulas for bed load transport. Proceedings of the 2nd Meeting of the Interna tional Association for Hydraulic Structures Research: 3964.

Milner, N. J., J. M. Elliott, J. D. Armstrong, R. Gardiner, J. S. Welton \& M. Ladle, 2003. The natural control of salmon and trout populations in streams. Fisheries Research 62: 111125.

Moeliker, C. W., 2001. The first case of homosexual necrophilia in the mallard Anas platyrhynchos (Aves: Anatidae). DEINSEA 8: 243247. 
Morantz, D. L., R. K. Sweeney, C. S. Shirvell \& D. A. Longard, 1987. Selection of microhabitat in summer by juvenile Atlantic salmon (Salmo salar). Canadian Journal of Fish eries and Aquatic Sciences 44: 120129.

Nash, J. E. \& J. V. Sutcliffe, 1970. River flow forecasting through conceptual models part I a discussion of princi ples. Journal of Hydrology 10: 282290.

Nitsche, M., D. Rickenmann, J. M. Turowski, A. Badoux \& J. W. Kirchner, 2011. Evaluation of bedload transport pre dictions using flow resistance equations to account for macro roughness in steep mountain streams. Water Resources Research 47: W08513.

Nujic, M., 1999. Praktischer Einsatz eines hochgenauen Ver fahrens für die Berechnung von tiefengemittelten Ström ungen. Mitteilungen des Institutes für Wasserwesen der Universität der Bundeswehr München. Nr. 64.

Nujic, M., 2004. Ergänzungen zu Hydro as 2d. Ein zweidi mensionales Modell für die wasserwirtschaftliche Praxis.

OcCC \& ProClim (Hrsg.), 2007. Klimaänderung und die Schweiz 2050. Erwartete Auswirkungen auf Umwelt. Gesellschaft und Wirtschaft, Bern.

Parry, M. L., O. F. Canziani, J. P. Palutikof, P. J. van der Linden \& C. E. Hanson, 2007. Contribution of Working Group II to the Fourth Assessment Report of the Intergovernmental Panel on Climate Change. Cambridge University Press, Cambridge.

Pironneau, P., 1989. Finite Element Methods for Fluids. Wiley, Chichester.

Pulg, U., B. T. Barlaup, K. Sternecker, L. Trepl \& G. Unfer, 2013. Restoration of spawning habitats of brown trout (Salmo trutta) in a regulated chalk stream. River Research and Applications 29: 172182.

Raeymaekers, J. A. M., D. Raeymaekers, I. Koizumi, S. Geldof \& F. A. M. Volckaert, 2009. Guidelines for restoring connectivity around water mills: a population genetic approach to the management of riverine fish. Journal of Applied Ecology 46: 562571.

Rickenmann, D., 2001. Comparison of bed load transport in torrents and gravel bed streams. Water Resources Research 37: 32953305.

Rickenmann, D., 2012. Alluvial steep channels: flow resistance, bedload transport and transition to debris flows. In Church, M., P. Biron \& A. Roy (eds), Gravel Bed Rivers: Processes, Tools, Environment. Wiley, Chichester: 386397.

Rickenmann, D. \& A. Recking, 2011. Evaluation of flow resistance equations using a large field data base. Water Resources Research 47: W07538.

Riedl, C. \& A. Peter, 2013. Timing of brown trout spawning in Alpine rivers with special consideration of egg burial depth. Ecology of Freshwater Fish 22: 384397.

Riley, W. D., D. L. Maxwell, M. G. Pawson \& M. J. Ives, 2009. The effects of low summer flow on wild salmon (Salmo salar), trout (Salmo trutta) and grayling (Thymallus thy mallus) in a small stream. Freshwater Biology 54: 25812599.

Rimmer, D. M., U. Paim \& R. L. Saunders, 1983. Autumnal habitat shift of juvenile Atlantic salmon (Salmo salar) in a small river. Canadian Journal of Fishery and Aquatic Sci ences 40: 671680.

Rimmer, D. M., U. Paim \& R. L. Saunders, 1984. Changes in the selection of microhabitat by juvenile Atlantic salmon
(Salmo salar) at the summer autumn transition in a small river. Canadian Journal of Fishery and Aquatic Sciences 41: 469475.

Schattan, P., M. Zappa, H. Lischke, L. Bernhard, E. Thürig \& B. Diekkrüger, 2013. An approach for transient consideration of forest change in hydrological impact studies. In: Climate and Land Surface Changes in Hydrology, IAHS IAPSO IASPEI Assembly, Gothenburg, Sweden (in press, March 2013).

Scheurer, K., C. Alewell, D. Baenninger \& P. Burkhardt Holm, 2009. Climate and land use changes affecting river sedi ment and brown trout in alpine countries a review. Environmental Science and Pollution Research 16: 232242.

Tritthart, M., C. Hauer, M. Liedermann \& H. Habersack, 2008. Computer aided mesohabitat evaluation, part II model development and application in river restoration of a large river. In: International Conference on Fluvial Hydraulics, River Flow 2008. 3. 5 9.2008.

Turowski, J. M., A. Badoux \& D. Rickenmann, 2011. Start and end of bedload transport in gravel bed streams. Geophys ical Research Letters 38: L04401.

Unfer, G., C. Hauer \& E. Lautsch, 2011. The influence of hydrology on the recruitment of brown trout in an Alpine river, the Ybbs River, Austria. Ecology of Freshwater Fish 20: 438448 .

Van der Linden, P. \& J. F. B. Mitchell, 2009. ENSEMBLES: climate change and its impacts: summary of research and results from the ENSEMBLES project. Met Office Hadley Centre, Exeter.

Verhaar, P. M., P. M. Biron, R. I. Ferguson \& T. B. Hoey, 2010. Numerical modelling of climate change impacts on Saint Lawrence River tributaries. Earth Surface Processes and Landforms 35: 11841198.

Verhaar, P. M., P. M. Biron, R. I. Ferguson \& T. B. Hoey, 2011. Implications of climate change in the twenty first century for simulated magnitude and frequency of bed material transport in tributaries of the Saint Lawrence River. Hydrology Processes 25: 5581573.

Viviroli, D., M. Zappa, J. Gurtz \& R. Weingartner, 2009. An introduction to the hydrological modelling system PRE VAH and its pre and post processing tools. Environmen tal Modelling \& Software 24: 12091222.

Wedekind, C. \& C. Kung, 2010. Shift of spawning season and effects of climate warming on developmental stages of a grayling (Salmonidae). Conservation Biology 24: 14181423.

Wedekind, C., M. O. Gessner, F. Vazquez, M. Maerki \& D. Steiner, 2010. Elevated resource availability sufficient to turn opportunistic into virulent fish pathogens. Ecology 91: 12511256.

Wentworth, C. K., 1922. A scale of grade and class terms for clastic sediments. Journal of Geology 30: 377392.

Weingartner, R., 1992. Abflussregimes als Grundlage zur Abs chätzung von Mittelwerten des Abflusses. Hydrologischer Atlas der Schweiz (Bundesamt für Umwelt BAFU, Bern.):Tafel 5.2.

Yamamoto, S., K. Morita, I. Koizumi \& K. Maekawa, 2004. Genetic differentiation of white spotted charr (Salvelinus leucomaenis) populations after habitat fragmentation: Spatial temporal changes in gene frequencies. Conserva tion Genetics 5: 529538. 
Zappa, M., L. Bernhard, F. Fundel \& S. Jörg Hess, 2012. Vor hersage und Szenarien von Schnee und Wasserressourcen im Alpenraum. Forum für Wissen 2012: 1927.

Zeh, M. \& W. Dönni, 1994. Restoration of spawning grounds for trout and grayling in the river high Rhine. Aquatic Sci ences 56: 5969 .

Zeh Weissmann, M., C. Könitzer \& A. Bertiller, 2009. Stru kturen der Fliessgewässer in der Schweiz. Zustand von Sohle, Ufer und Umland (Ökomorphologie); Ergebnisse der Ökomorphologischen Kartierung. Stand: April 2009. Umwelt Zustand Nr. 0926.

Zierl, B. \& H. Bugmann, 2005. Global change impacts on hydrological processes in Alpine catchments. Water Resources Research 41: W02028.

Zimmer, M. P. \& M. Power, 2006. Brown trout spawning habitat selection preferences and redd characteristics in the Credit River, Ontario. Journal of Fish Biology 68: 13331346. 